\title{
Development of a Scalable Route for a Highly Polar Heterocyclic Aminocyclopropyl Building Block
}

\author{
Gabriel Schäfer, ${ }^{*}$ Muhamed Ahmetovic, Tony Fleischer and Stefan Abele \\ Chemistry Process R\&D, Idorsia Pharmaceuticals Ltd., Hegenheimermattweg 91, \\ 4123 Allschwil, Switzerland \\ Email: gabriel.schaefer@idorsia.com
}

\section{Supporting Information}

\section{Table of Contents}

Table of Contents

1. Procedures

Page

1.1 Cyclopropanation Procedure

1.2 Negishi Coupling Procedure $\quad 4$

1.3 Cyclization with 3-dimethylaminoacrolein $\quad 5$

2. Process safety data on Cyclizations with 3-Dimethylaminoacrolein $\quad 7$

3. Process safety data on Cyclization with 20-PF 6

4. NMR, DSC, HPLC and XRPD Analysis 12 


\section{Procedures}

\subsection{Cyclopropanation Procedure}

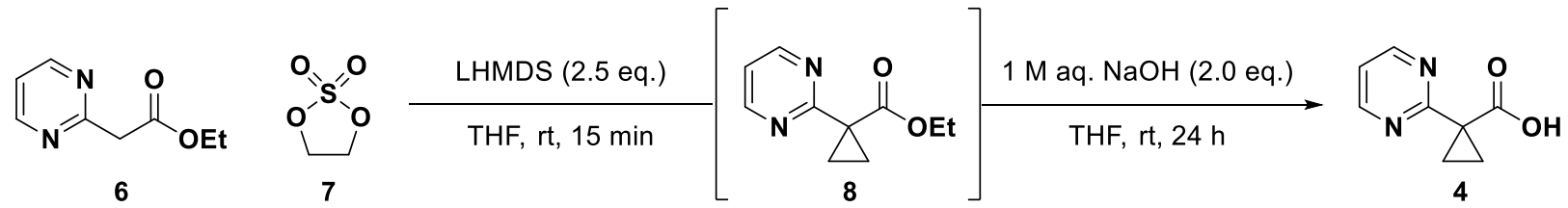

Under $\mathrm{N}_{2}$-atmosphere, a $1 \mathrm{~L}$ three-necked flask was charged with 2-pyrimidine acetic-acid ethylester 6 (17.3 g, 0.104 mol, 1.00 eq.), 1,3,2-Dioxathiolane 2,2-dioxide 7 (25.8 g, 0.208 mol, 2.00 eq.) and dry THF (87 mL, 5 vol.). The flask was placed into an ambient $\mathrm{H}_{2} \mathrm{O}$-bath and then LHMDS (173 mL of $1.5 \mathrm{M}$ solution in THF, $0.260 \mathrm{~mol}, 2.50$ eq.) was added dropwise via dropping funnel over 30 min (exothermic reaction, IT kept below $30^{\circ} \mathrm{C}$ ). The colorless reaction mixture turned orange. The reaction mixture was stirred at it for $30 \mathrm{~min}$ (>98\% conversion of 6 to 8).

$1 \mathrm{M}$ aq. $\mathrm{NaOH}$ (208 mL, $0.208 \mathrm{~mol}, 2.00$ eq.) was added rapidly at rt and the reaction mixture was stirred at rt overnight ( $>98 \%$ conversion of $\mathbf{8}$ to 4 ). The reaction mixture was quenched by dropwise addition of $32 \%$ aq. $\mathrm{HCl}$ (ca. $45 \mathrm{~mL}$ ) and the THF was removed under red pressure at the rotavap $\left(55^{\circ} \mathrm{C}, 200 \mathrm{mBar}\right)$. The resulting aqueous suspension was cooled to $\mathrm{rt}$ and aged for $1 \mathrm{~h}$. The product was collected by filtration, washed with $\mathrm{H}_{2} \mathrm{O}(2 \times 25 \mathrm{~mL})$ and then dried at 65 ${ }^{\circ} \mathrm{C}$ under vacuum for $5 \mathrm{~h}$ to give $4(9.95 \mathrm{~g}, 0.0606 \mathrm{~mol}, 58 \%)$ as light pink solid. LC/MS purity: $>99 \%$ a/a. m.p. $174{ }^{\circ} \mathrm{C}$ (DSC); ${ }^{1} \mathrm{H}$ NMR (400 MHz, d6-DMSO) 13.6 (s, 1H), 8.77 (d, J = $4.8 \mathrm{~Hz}$, 2H), $7.41(\mathrm{t}, J=4.8 \mathrm{~Hz}, 1 \mathrm{H}), 1.57(\mathrm{~m}, 1 \mathrm{H}), 1.50(\mathrm{~m}, 1 \mathrm{H}) ;{ }^{13} \mathrm{C}$ NMR (101 MHz, d6-DMSO) 173.0, 167.2, 157.0, 119.3, 39.5, 30.3, 18.6. HRMS (ESI) m/z calcd for $\mathrm{C}_{8} \mathrm{H}_{9} \mathrm{~N}_{2} \mathrm{O}_{2}([\mathrm{M}+\mathrm{H}]+)$ : 165.0659 . Found: 165.0663. 

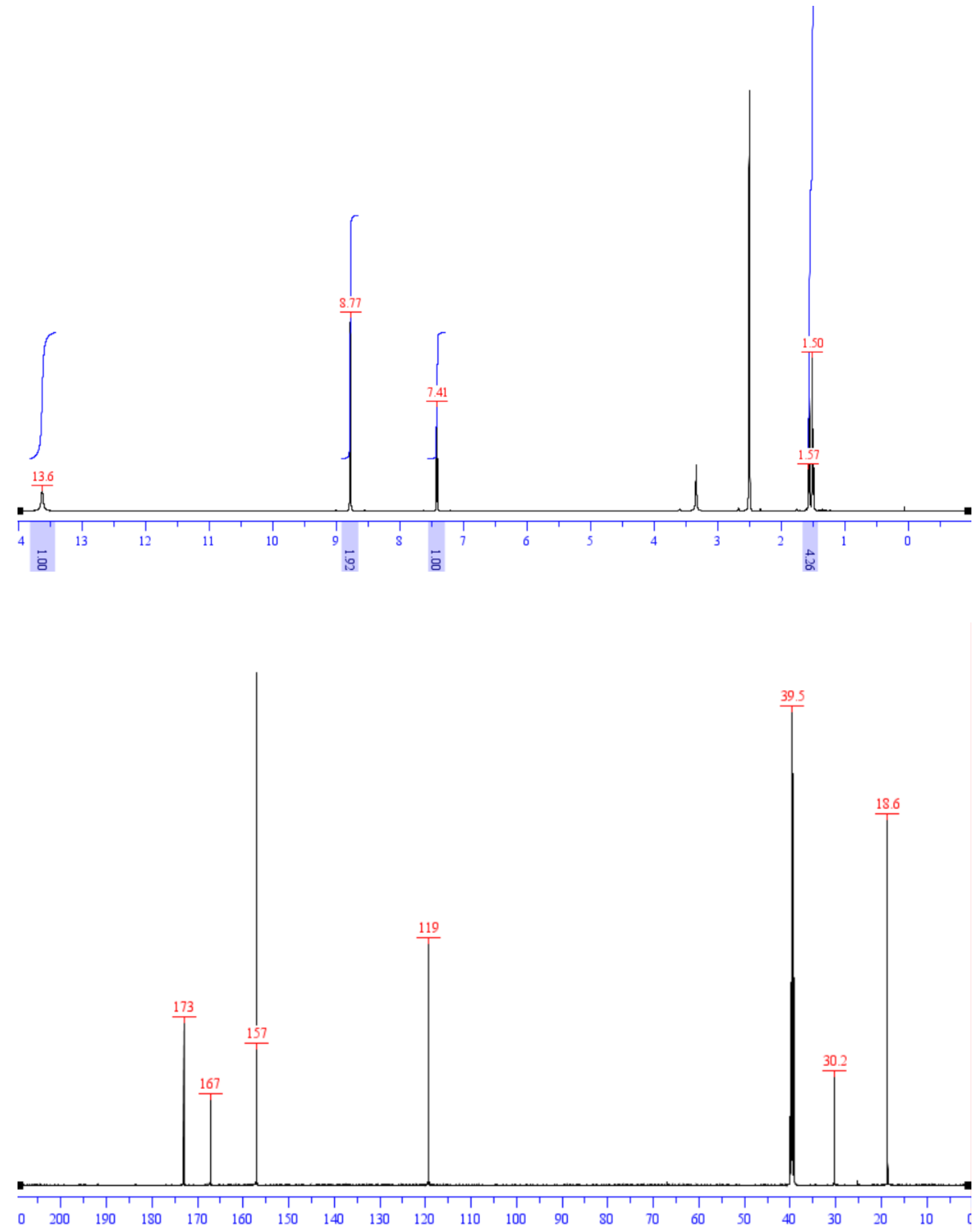
1.2 Negishi Coupling Procedure

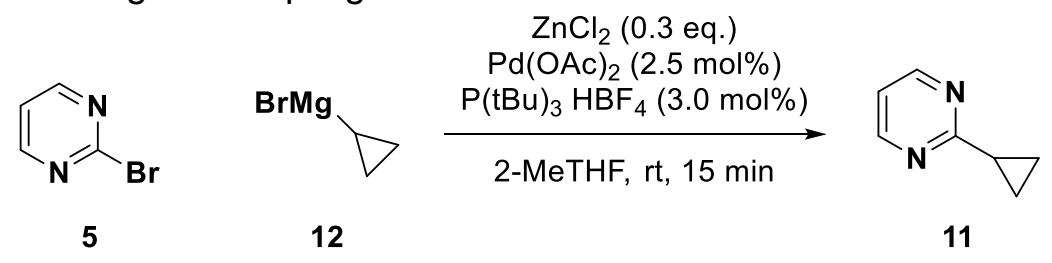

Under $\mathrm{N}_{2}$-atmosphere, a $500 \mathrm{~mL}$ three-necked flask was charged 2-bromopyrimidine 5 (10.0 g, $62.9 \mathrm{mmol}, 1.00$ eq.), $\mathrm{Pd}(\mathrm{OAc})_{2}$ (353 mg, $1.57 \mathrm{mmol}, 0.025$ eq.) tri-tert-butylphosphonium tetrafluoroborate (547 mg, $1.89 \mathrm{mmol}, 0.030$ eq.) and dry 2-MeTHF (50 mL, 5 vol.). $\mathrm{ZnCl}_{2}$ (10 $\mathrm{mL}$ of $1.9 \mathrm{M}$ solution in 2-MeTHF, $18.9 \mathrm{mmol}, 0.30$ eq.) was added rapidly (not exothermic). The reaction mixture was placed into an ambient $\mathrm{H}_{2} \mathrm{O}$-bath and cyclopropylmagnesium bromide 12 ( $85 \mathrm{~mL}$ of $1.0 \mathrm{M}$ solution in 2-MeTHF, $85.0 \mathrm{mmol}, 1.35$ eq.) was added dropwise over $1 \mathrm{~h}$ via dropping funnel (exothermic addition, IT kept below $30^{\circ} \mathrm{C}$ ). The reaction mixture was stirred at $\mathrm{rt}$ for $15 \min$ (>98\% conversion of 5 to 11 ).

The reaction mixture was cooled to $0{ }^{\circ} \mathrm{C}$ with an ice-bath and quenched by dropwise addition of $\mathrm{H}_{2} \mathrm{O}$ (50 mL, 5 vol.). The phases were separated and the organic phase washed with sat. aq. $\mathrm{NaCl}$ (25 mL, 2.5 vol.), dried over $\mathrm{Na}_{2} \mathrm{SO}_{4}$, filtered and conc under red pressure at the rotavap $\left(45^{\circ} \mathrm{C}, 100 \mathrm{mBar}\right.$ ) to obtain a dark crude oil. The crude was purified by Kugelrohr distillation $\left(150{ }^{\circ} \mathrm{C}, 20 \mathrm{mBar}\right.$ ) to obtain 11 a clear, colorless liquid (5.5 g, $45.8 \mathrm{mmol}, 73 \%$ ). LC/MS purity: 92\% a/a; ${ }^{1} \mathrm{H}$ NMR (400 MHz, $\left.\mathrm{CDCl}_{3}\right) 8.50(\mathrm{~d}, J=5.0 \mathrm{~Hz}, 2 \mathrm{H}), 7.00(\mathrm{t}, J=5.0 \mathrm{~Hz}, 1 \mathrm{H}), 2.20(\mathrm{~m}$, $1 \mathrm{H}), 1.07(\mathrm{~m}, 1 \mathrm{H}), 1.03(\mathrm{~m}, 1 \mathrm{H})$. Spectral data in accordance with literature report: Han, C.; Buchwald, S. L. J. Am. Chem. Soc. 2009, 131, 7532. 
1.3 Cyclization with 3-dimethylaminoacrolein

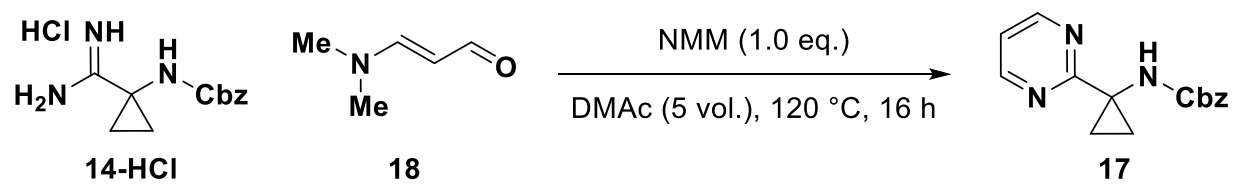

Under $\mathrm{N}_{2}$-atmosphere, a $250 \mathrm{~mL}$ round-bottom flask with attached reflux condenser was charged with benzyl (1-carbamimidoylcyclopropyl)carbamate hydrochloride 14-HCl $(10.0 \mathrm{~g}, 37.1$ mmol, 1.00 eq.) and DMAc (50 mL, 5 vol.). NMM (4.08 mL, $37.1 \mathrm{mmol}, 1.00$ eq.) and 3dimethylaminoacrolein $(7.40 \mathrm{~mL}, 74.1 \mathrm{mmol}, 2.00$ eq.) were rapidly added at $\mathrm{rt}$. The reaction mixture was heated to $\mathrm{ET}=120^{\circ} \mathrm{C}$ and stirred for $16 \mathrm{~h}$ (>98\% conversion of $14-\mathrm{HCl}$ to 17 ).

The reaction mixture was cooled to rt and quenched with $10 \%$ aq. citric acid $(50 \mathrm{~mL}, 5$ vol.). CPME (100 mL, 10 vol.) was added and the phases were separated. The aqueous phase was extracted with CPME (50 mL, 5 vol.). The combined organic phases were washed twice with sat. aq. $\mathrm{NaCl}\left(2 \times 50 \mathrm{~mL}, 2 \times 5\right.$ vol.), dried over $\mathrm{Na}_{2} \mathrm{SO}_{4}$, filtered and conc under red pressure at the rotavap $\left(55^{\circ} \mathrm{C}\right)$ to obtain a dark crude oil ( $85 \%$ a/a purity).

The crude product was taken up in CPME (30 mL, 3 vol.) and heated to ET $=70{ }^{\circ} \mathrm{C}$. To the brown solution was slowly added methylcyclohexane $(50 \mathrm{~mL}, 5 \mathrm{vol}$.) until crystallization of the product was observed. The resulting suspension was cooled to $\mathrm{rt}$ and aged for $1 \mathrm{~h}$. The product was collected by filtration, washed with methylcyclohexane $(2 \times 15 \mathrm{~mL})$ and then dried at $65{ }^{\circ} \mathrm{C}$ under vacuum for $4 \mathrm{~h}$ to give $17(6.88 \mathrm{~g}, 25.5 \mathrm{mmol}, 69 \%)$ as a tan solid. LC/MS purity: >99\% a/a. m.p. $89 \stackrel{\circ}{\circ} \mathrm{C}$ (DSC); ${ }^{1} \mathrm{H}$ NMR (400 MHz, d6-DMSO) (mixture of rotamers) 8.69 (d br, $J=5.0$ $\mathrm{Hz}, 2.5 \mathrm{H}), 8.08(\mathrm{~s}, 1 \mathrm{H}), 7.78(\mathrm{~s}, 0.25 \mathrm{H}), 7.40(\mathrm{~m}, 4 \mathrm{H}), 7.31(\mathrm{~m}, 1 \mathrm{H}), 7.25(\mathrm{~m}, 2 \mathrm{H}), 7.10(\mathrm{~d} b r, J=$ $6.3 \mathrm{~Hz}, 0.5 \mathrm{H}), 5.06(\mathrm{~s}, 2 \mathrm{H}), 5.01(\mathrm{~s}, 0.5 \mathrm{H}), 1.52(\mathrm{~m}, 2.5 \mathrm{H}), 1.27(\mathrm{~m}, 2.5 \mathrm{H}) ;{ }^{3} \mathrm{C}$ NMR $(101 \mathrm{MHz}$, d6-DMSO) 170.4, 170.2, 157.0, 156.7, 137.2, 128.3, 128.1, 127.7, 127.6, 127.3, 126.7, 118.3, 65.1, 37.4, 37.0, 19.9, 19.4. HRMS (ESI) m/z calcd for $\mathrm{C}_{15} \mathrm{H}_{16} \mathrm{~N}_{3} \mathrm{O}_{2}([\mathrm{M}+\mathrm{H}]+): 270.1237$. Found: 270.1245 . 

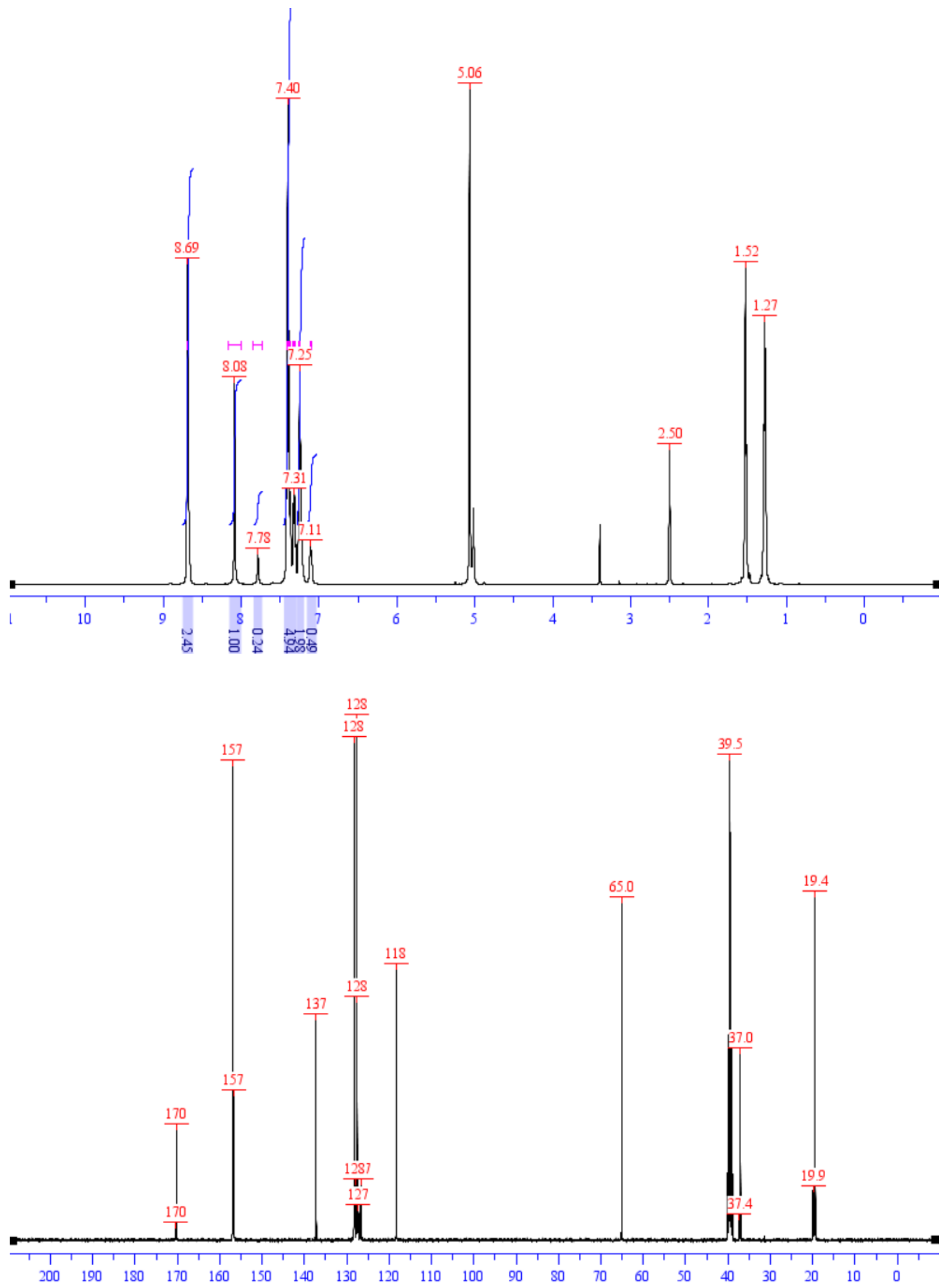


\section{Process safety data on Cyclizations with 3-Dimethylaminoacrolein}

\section{DSC of 3-Dimethylaminoacrolein}

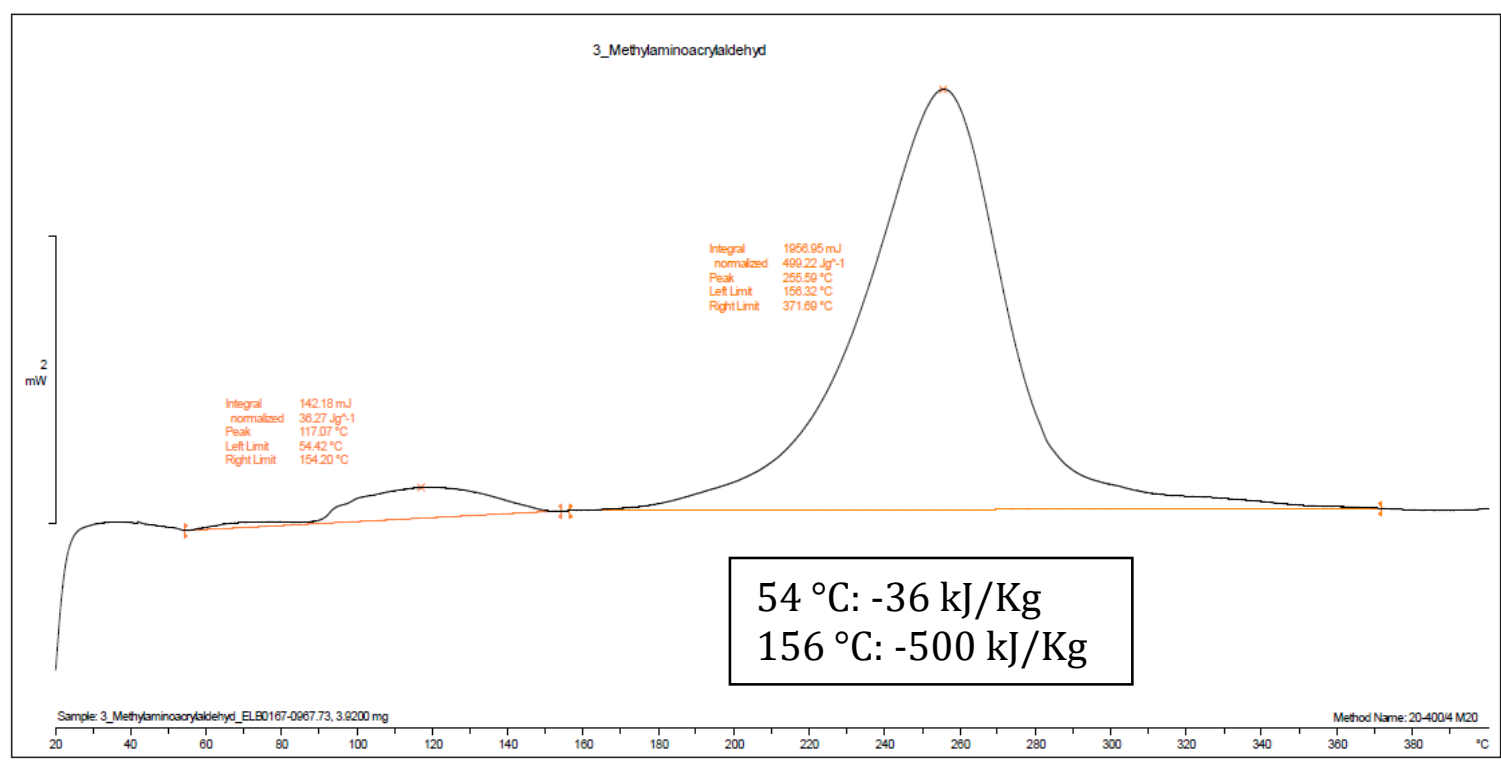

$\underline{D S C}$ of reaction mixture

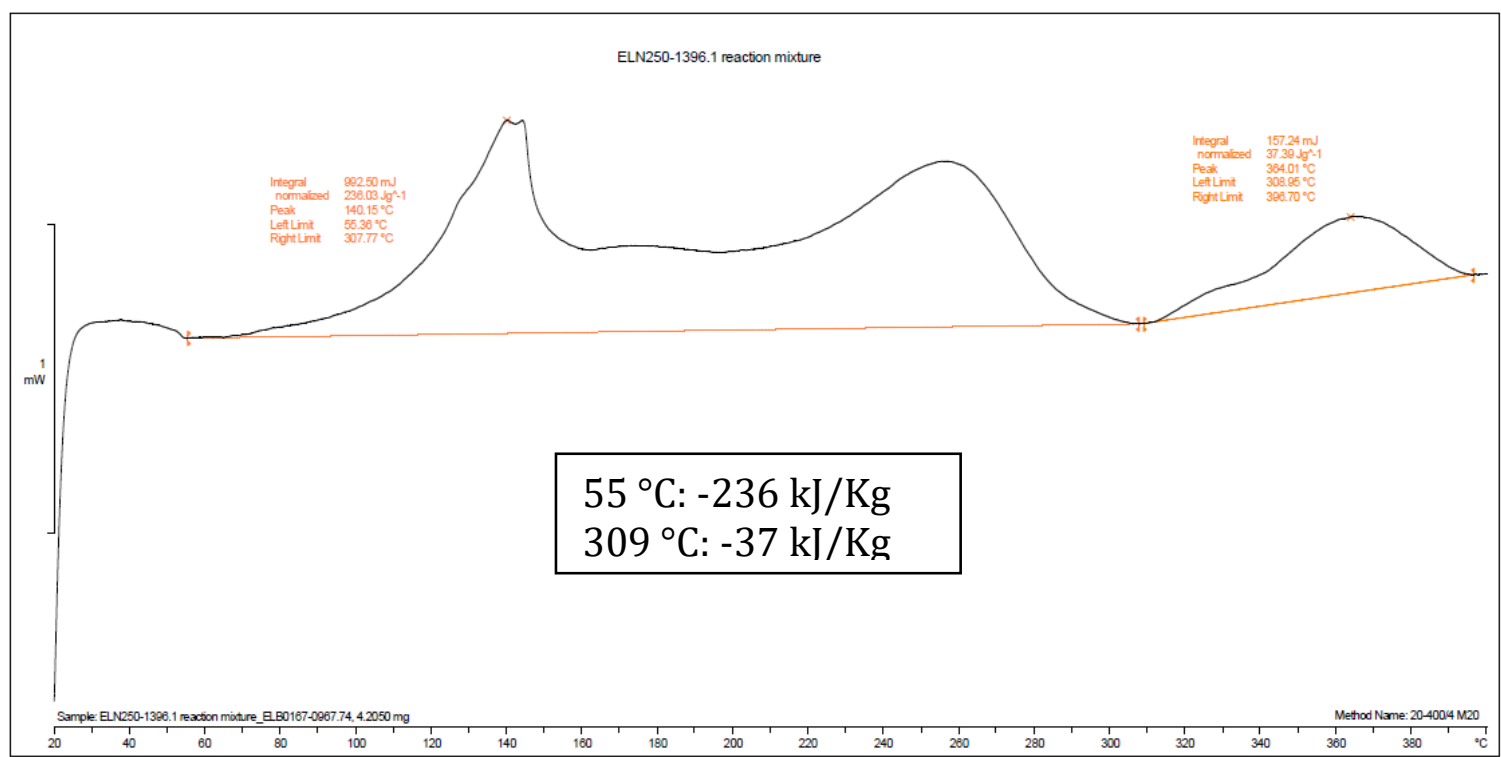




\section{Reaction in Thermal Scanning Unit (TSU) from HEL}

Reaction mixture after addition of NMM and 3-Dimethylaminoacrolein at rt was subjected into 10 $\mathrm{mL}$ sample cell from HEL and TSU run was performed. Measured was reaction exotherm and generated pressure release during the event.

\section{Isothermal at $120^{\circ} \mathrm{C}$}

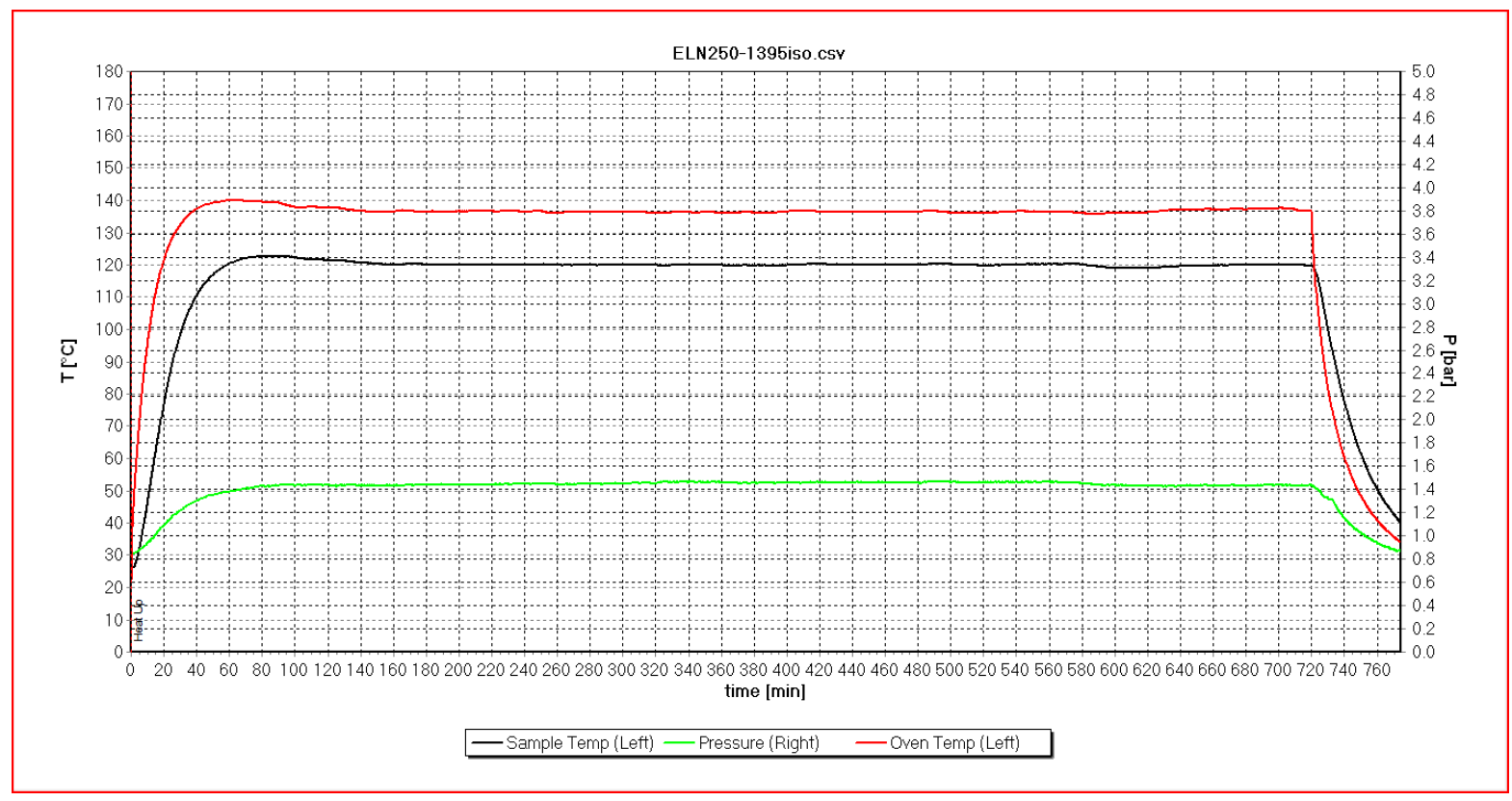

\section{Heat ramp}

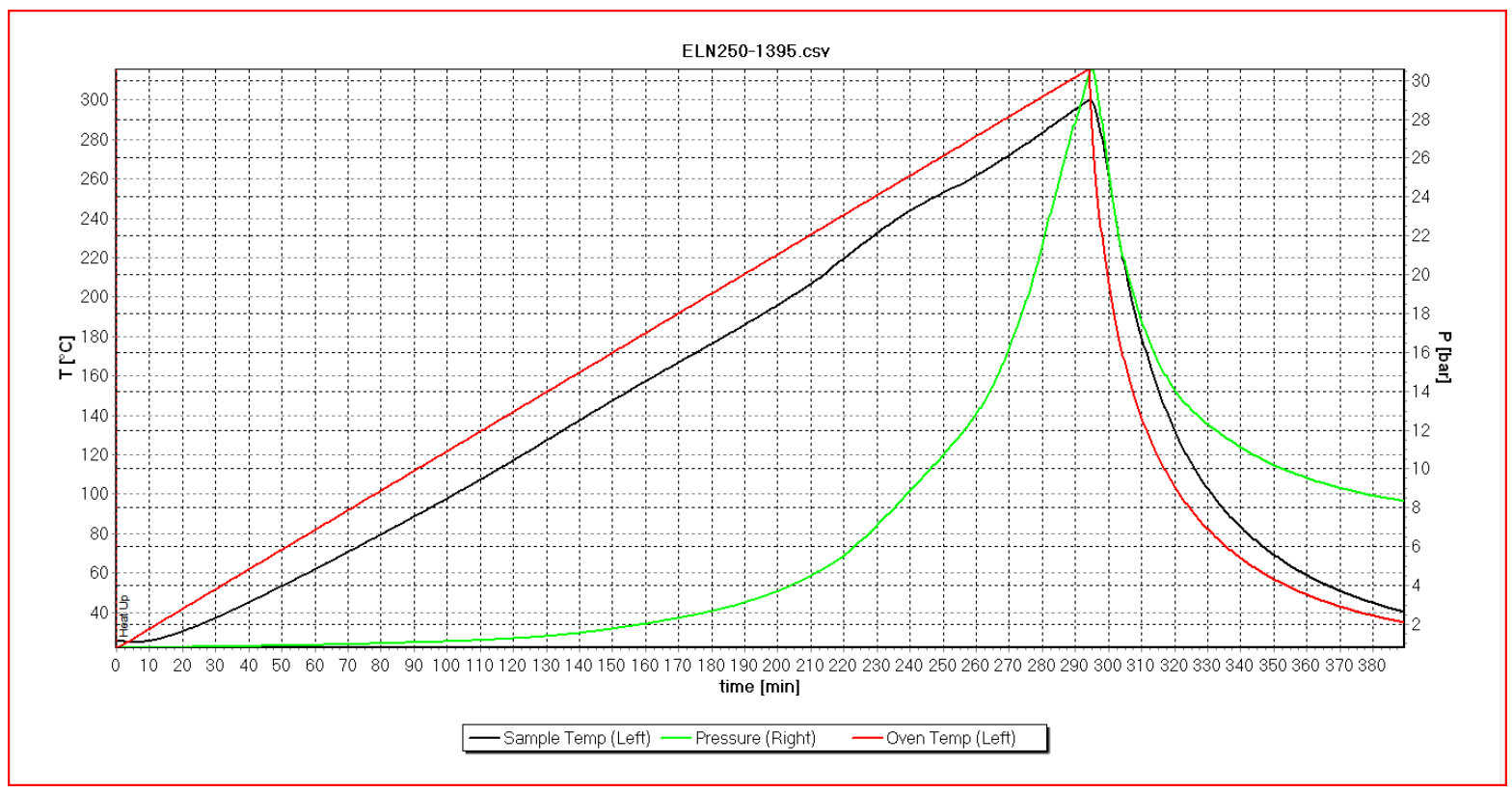




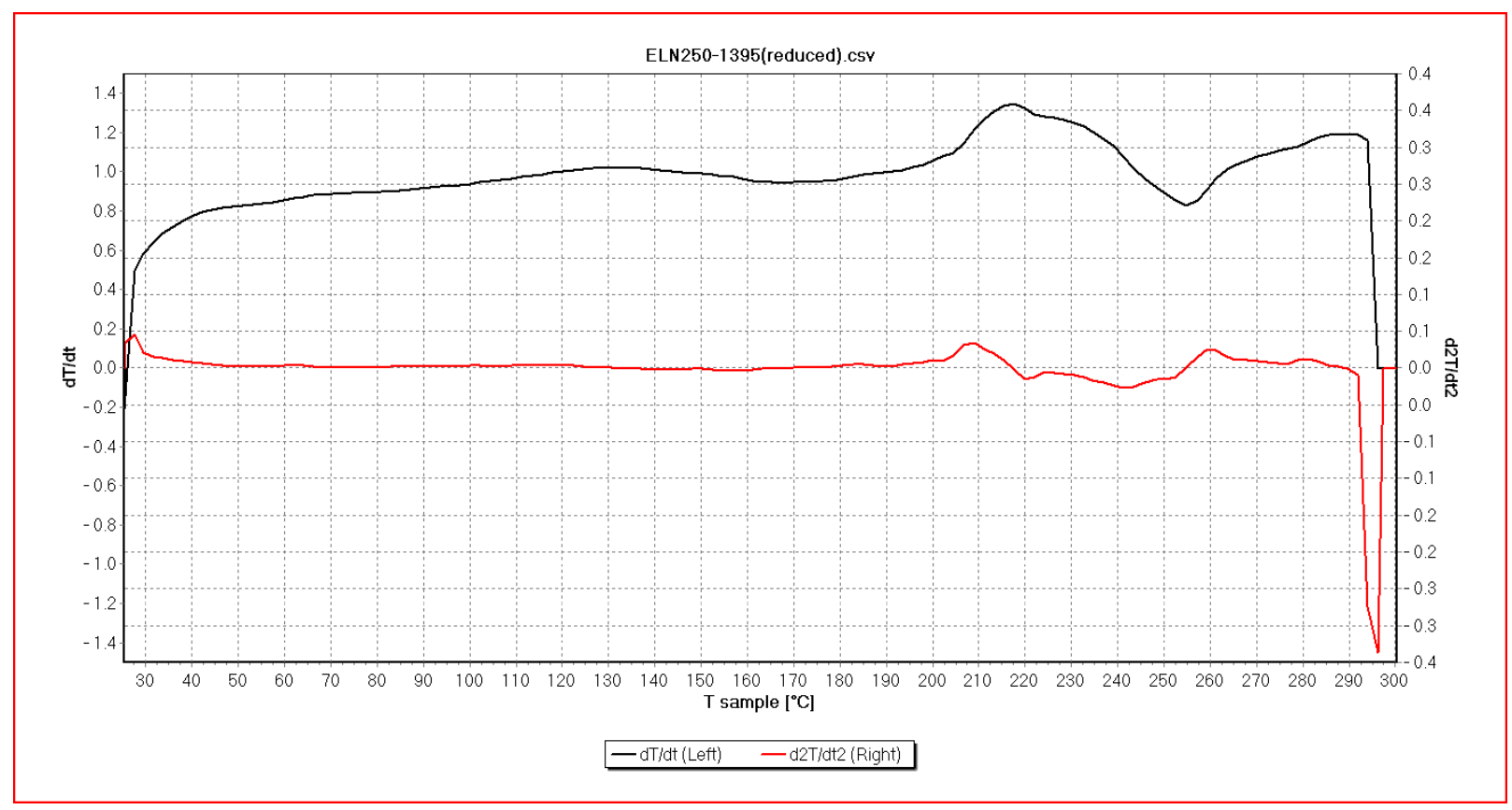




\section{Process safety data on Cyclization with $20-\mathrm{PF}_{6}$}

\section{DSC of 20-PF6}

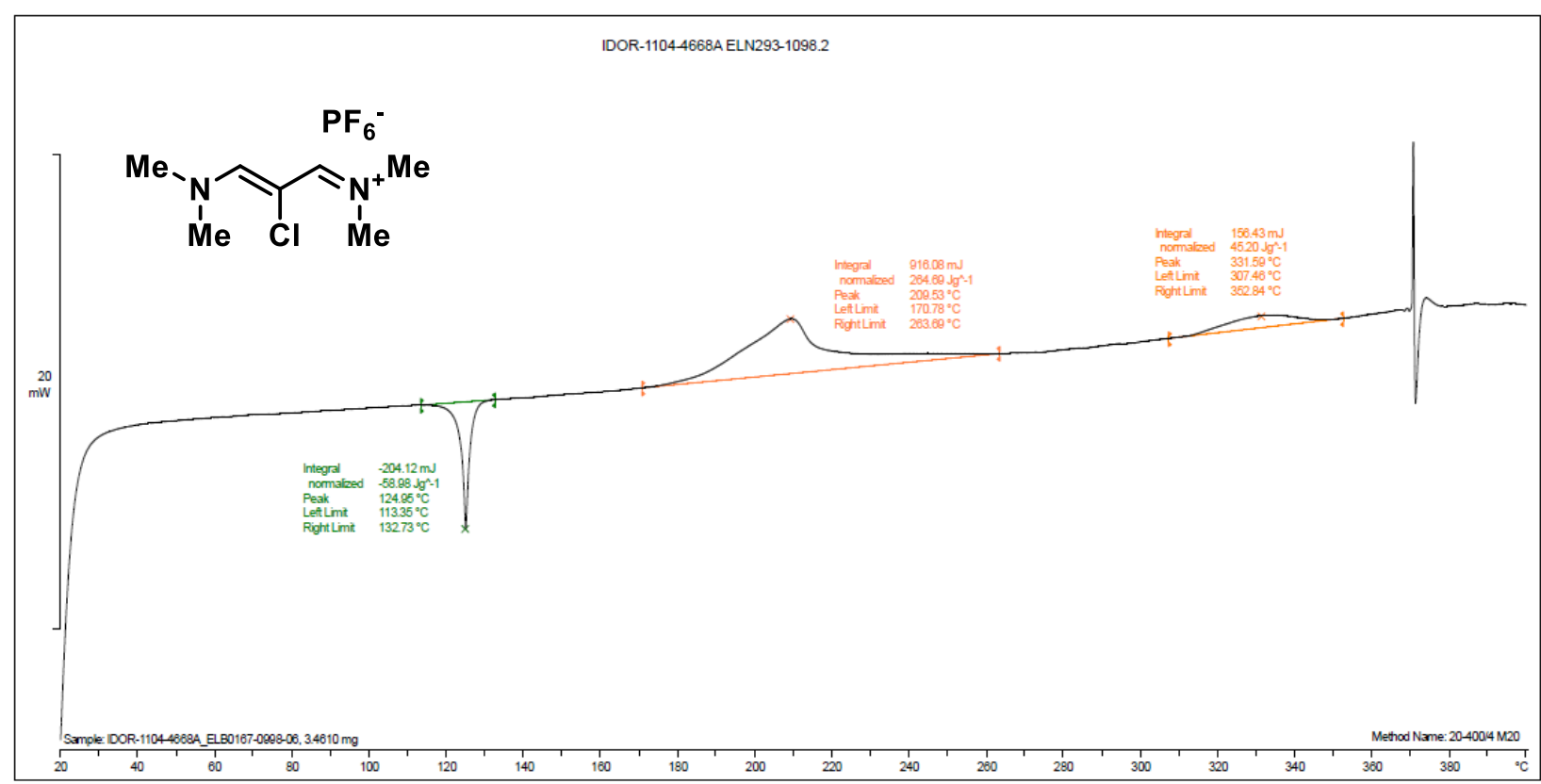

\section{Reaction in Thermal Scanning Unit (TSU) from HEL}

Reaction mixture after addition of NMM at rt was subjected into $10 \mathrm{~mL}$ sample cell from HEL and TSU run was performed. Measured was reaction exotherm and generated pressure release during the event.

\section{$\underline{\text { TSU isomethermal at } 75^{\circ} \mathrm{C}}$}

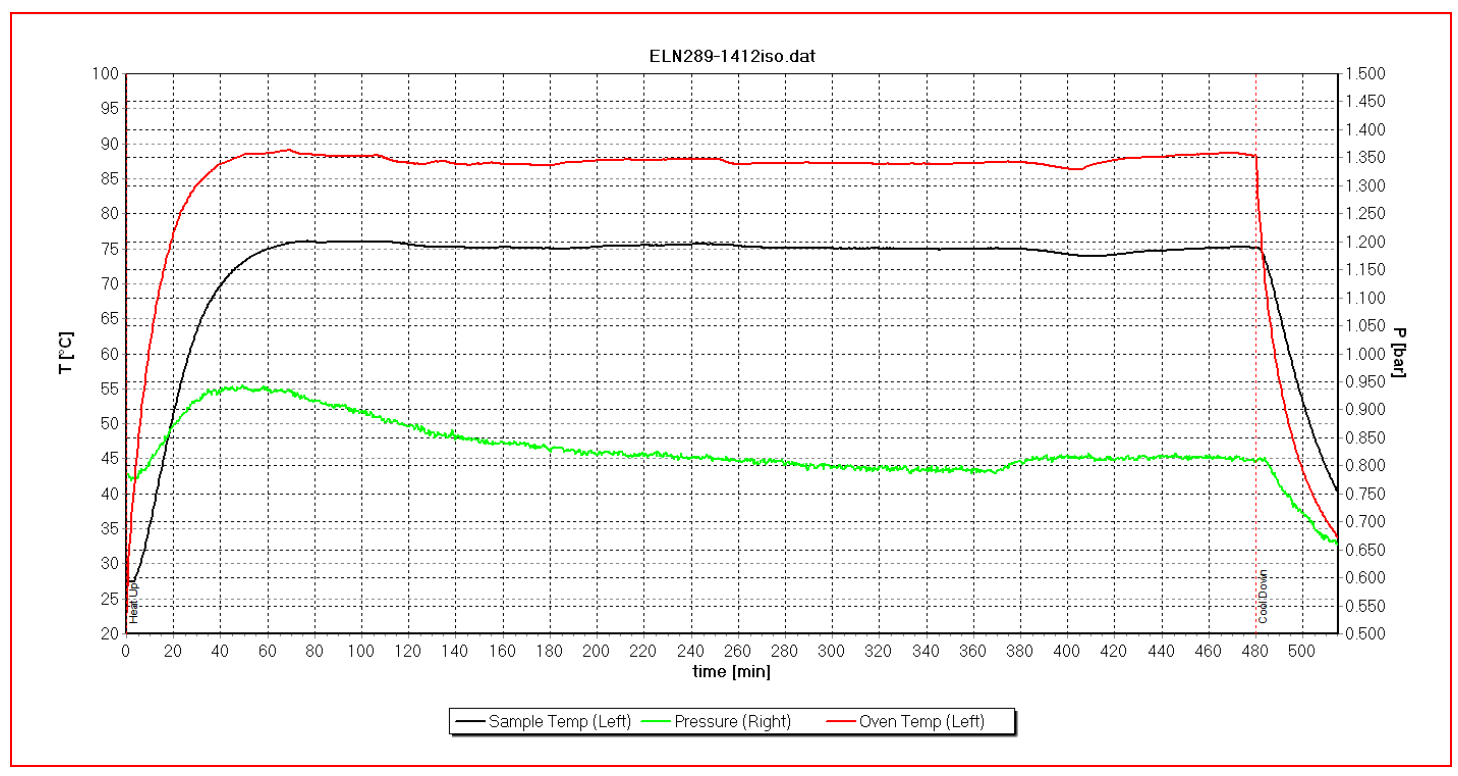




\section{$\underline{\text { TSU heat ramp }}$}
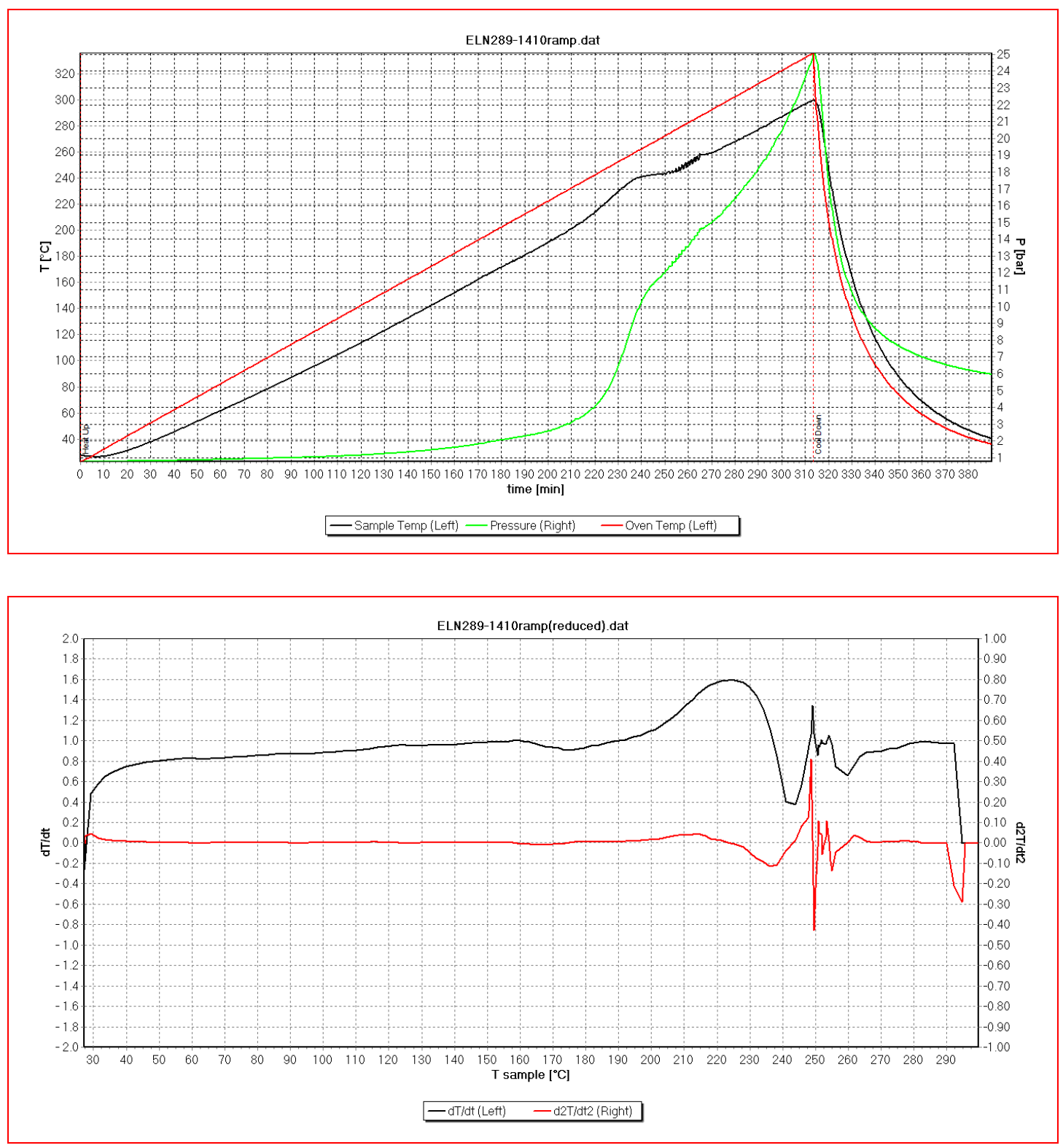


\section{NMR, DSC, HPLC and XRPD Analysis}

benzyl (1-cyanocyclopropyl)carbamate (15)
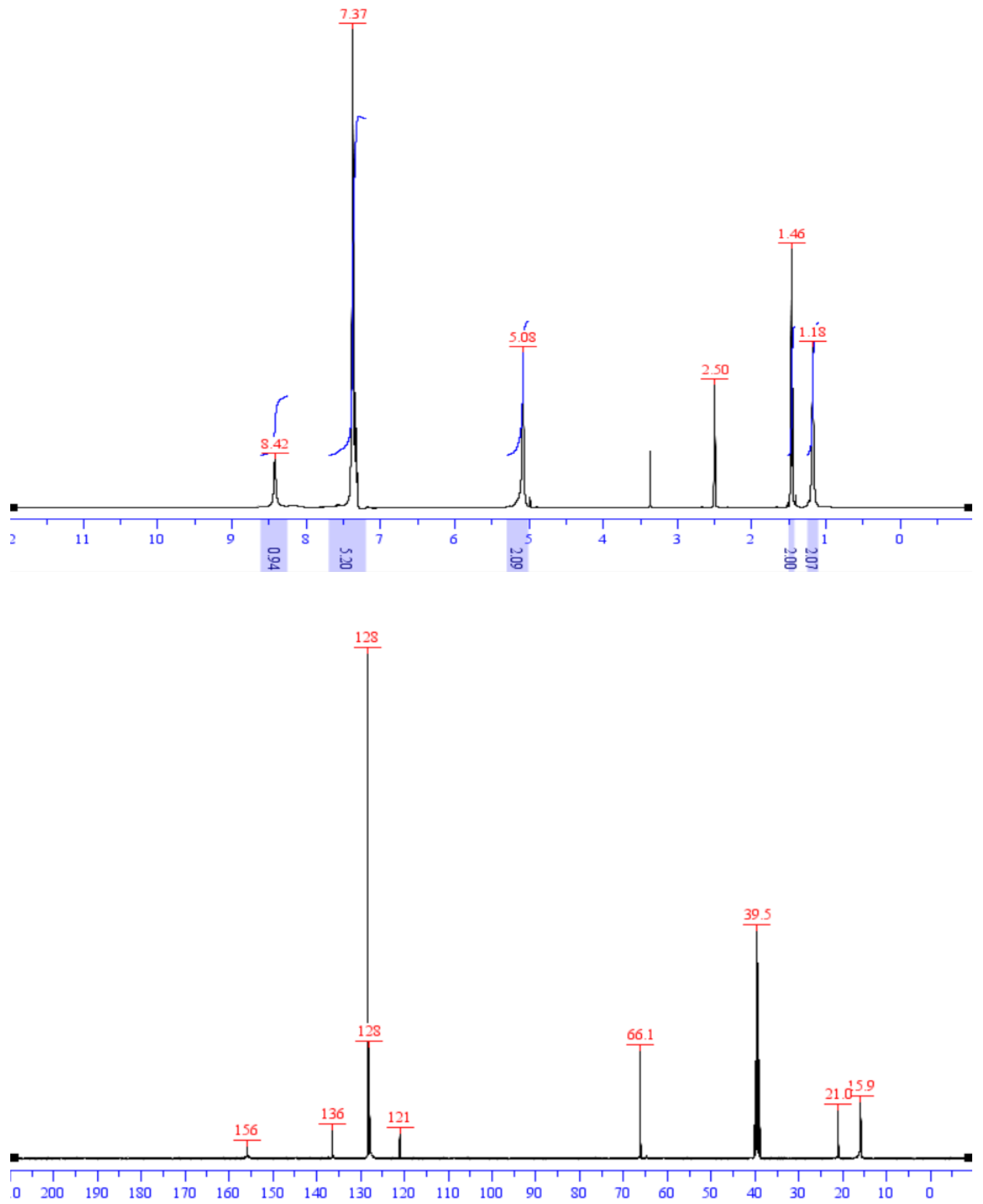
HPLC trace of 15 from $0.5 \mathrm{~kg}$ run

Inject Vol.: $\quad 0.15$ ul

Eluent $A$ : $\quad$ Water $0.04 \%$ TFA

Eluent B: $\quad$ Acetonitrile

Column: $\quad$ Zorbax RRHD SB-Aq, 2.1x50mm, 1.8um/USEAF01646

Time Base: $\quad$ iClass-MS02

Program Name: G_005\%B_TFA_0,800ml_2,00min_150-750amu_ESIplus lonisation: ESI+

Quantif. Method: default_26_002

Wavelength: $210 \mathrm{~nm}$

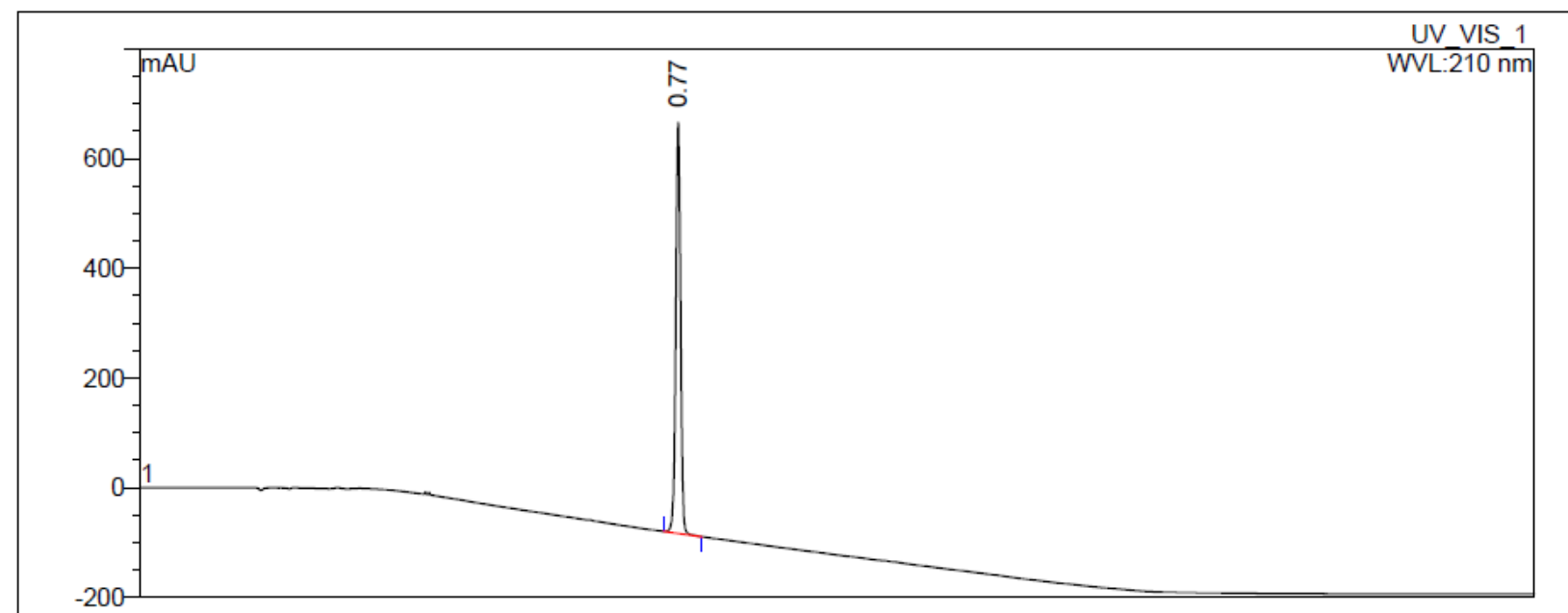

DSC of 15

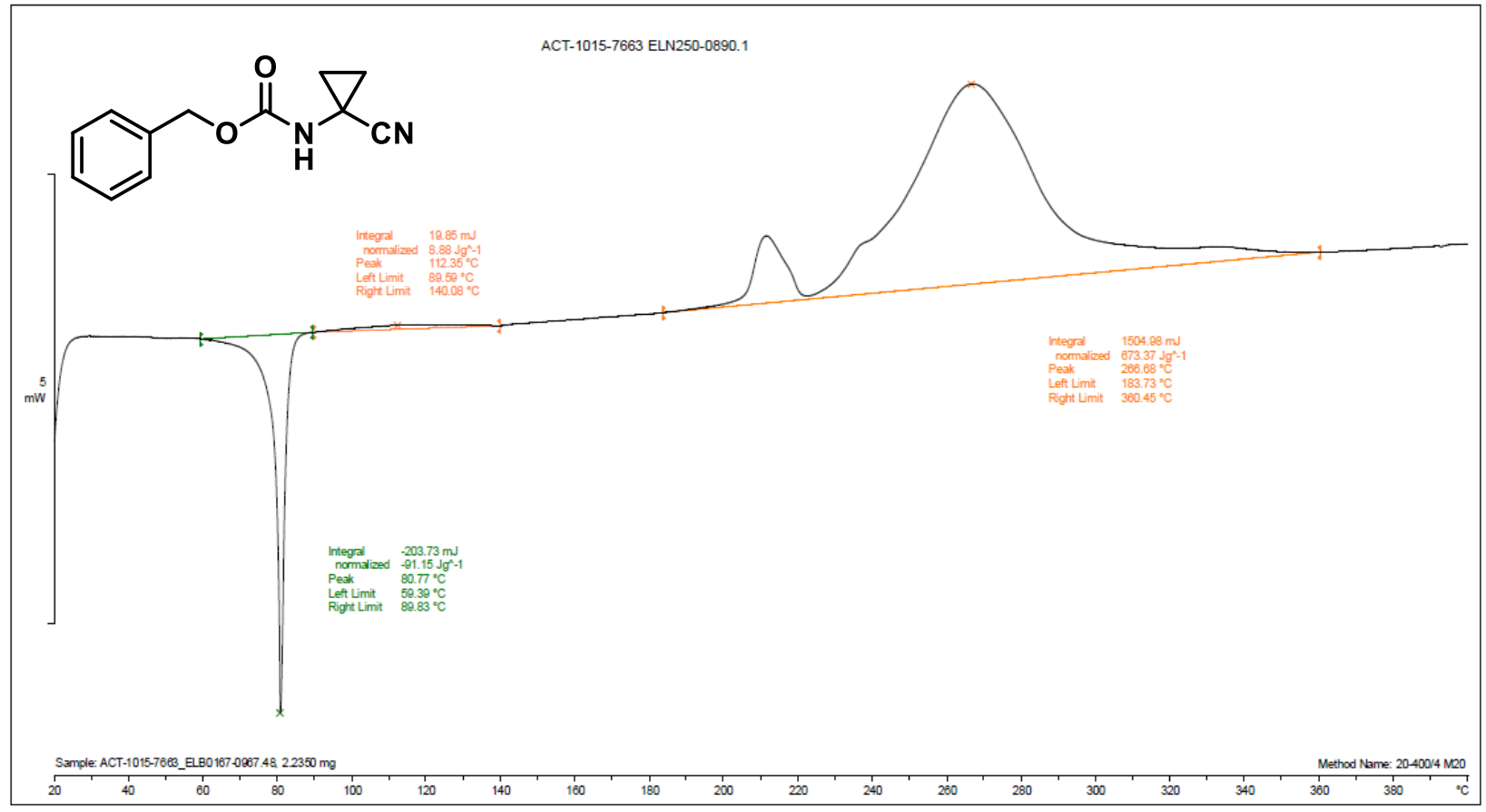


methyl 1-(((benzyloxy)carbonyl)amino)cyclopropane-1-carbimidate hydrochloride $(\mathbf{1 6}-\mathrm{HCl})$
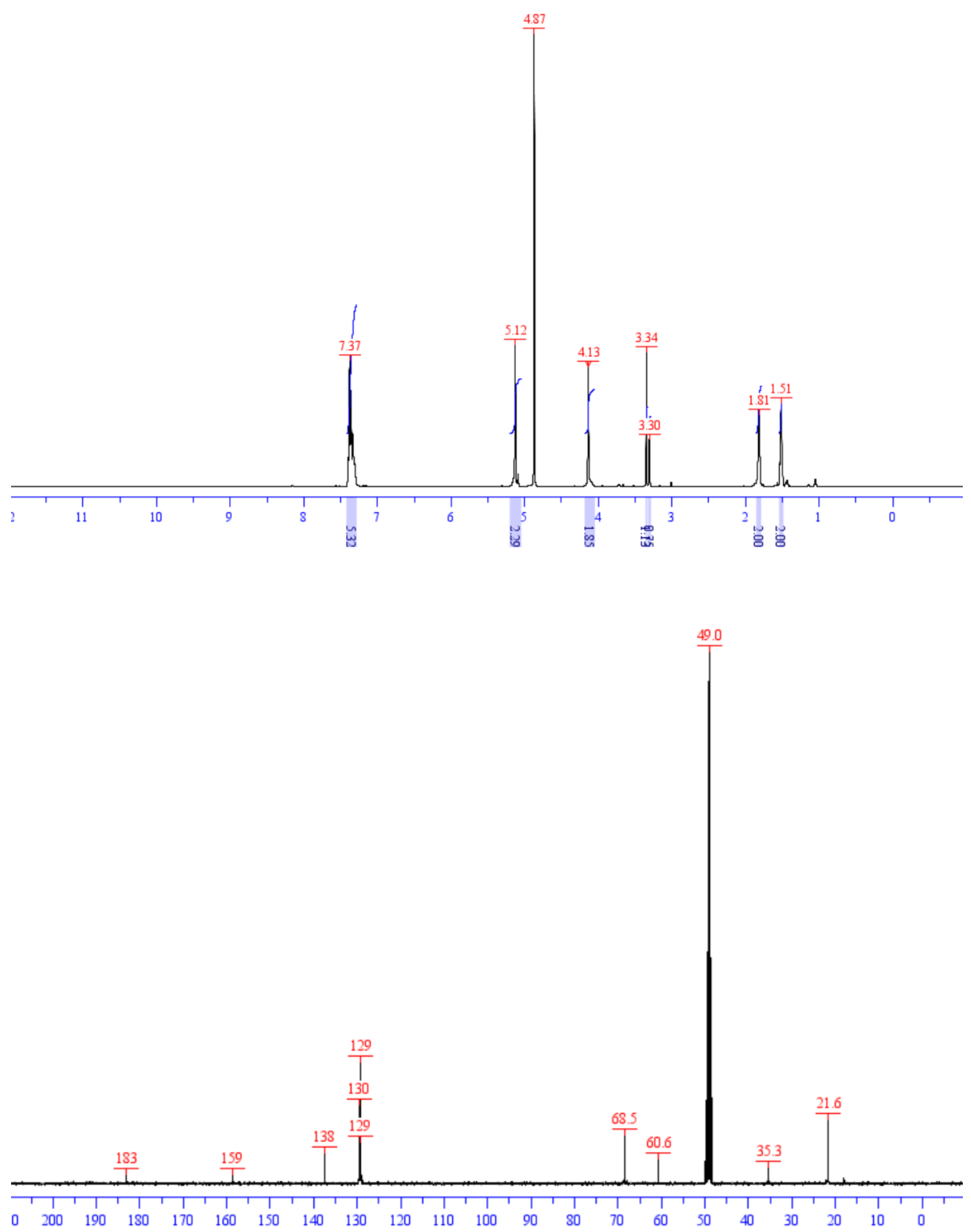
HPLC trace of $16-\mathrm{HCl}$ from $0.61 \mathrm{~kg}$ run

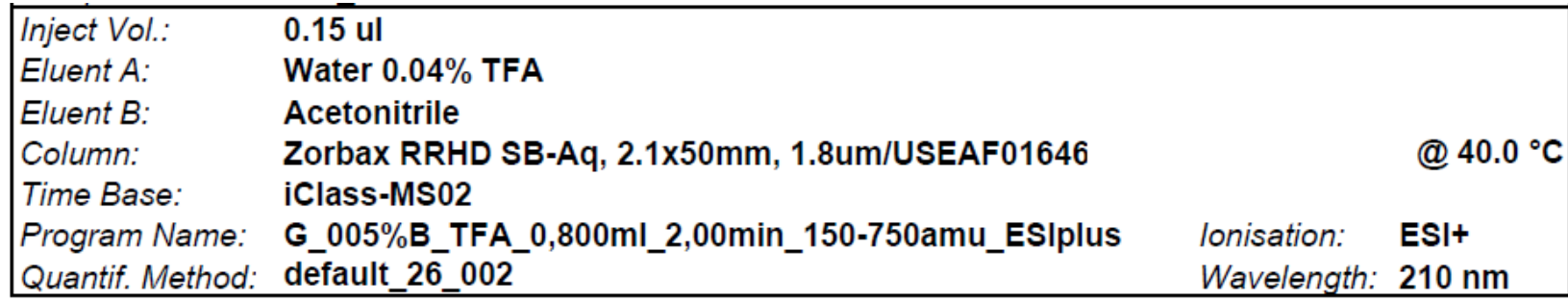

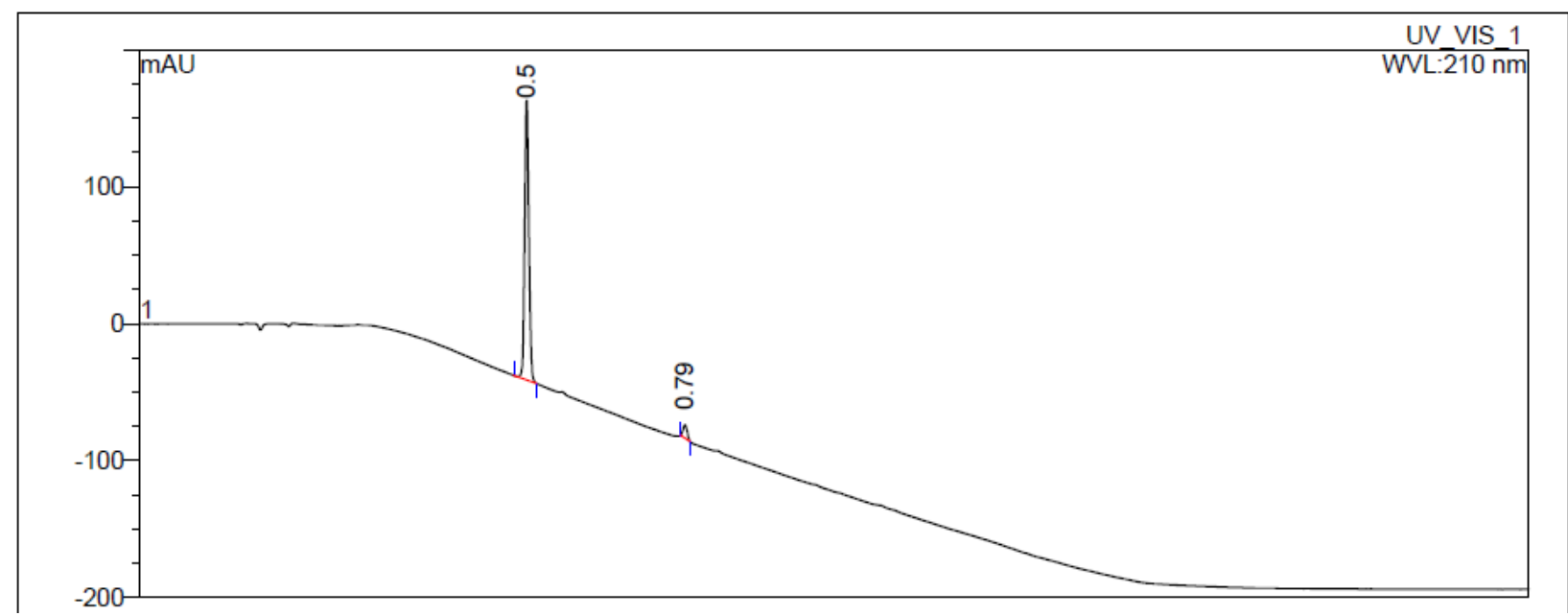

\section{DSC of $16-\mathrm{HCl}$}

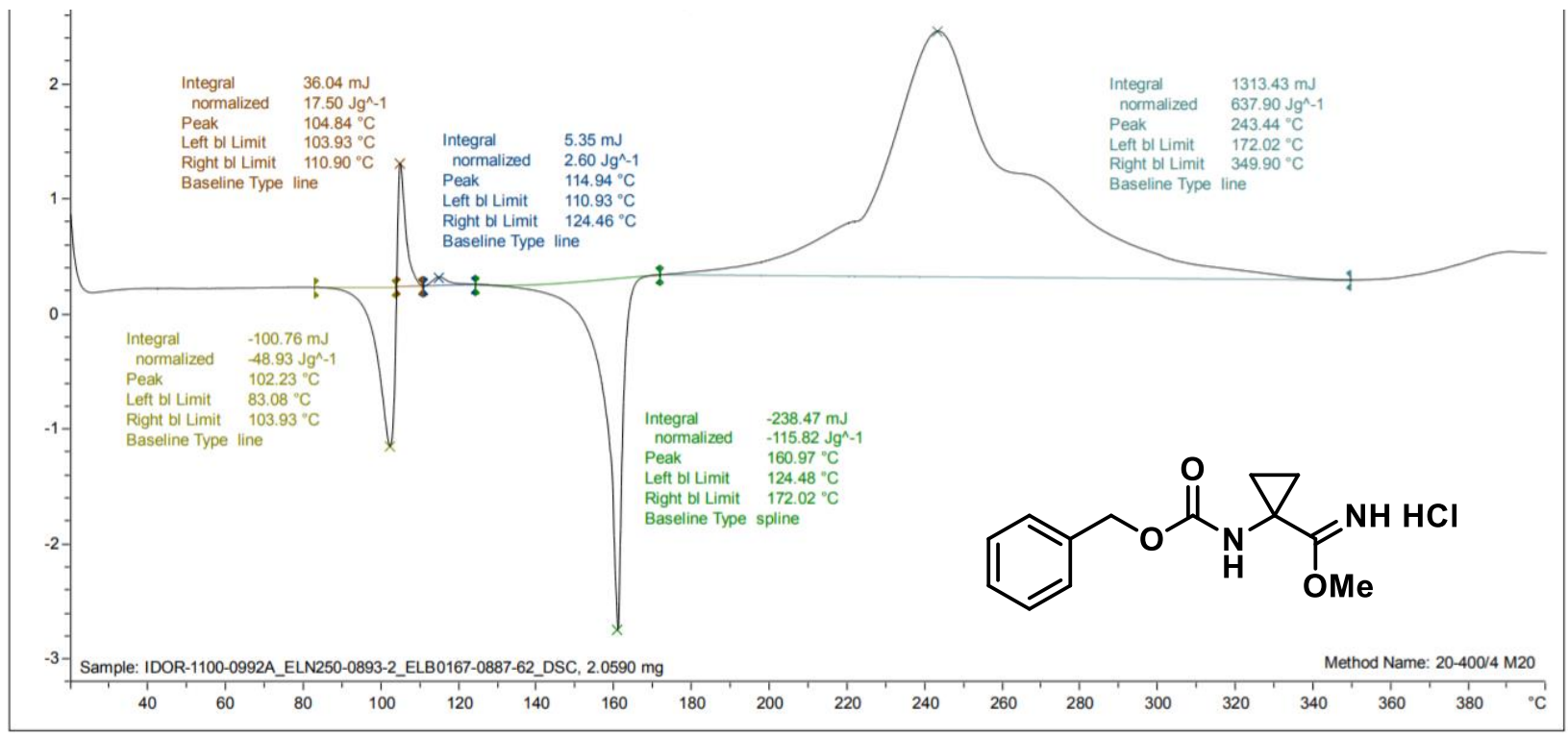


benzyl (1-carbamimidoylcyclopropyl)carbamate hydrochloride (14-HCl)
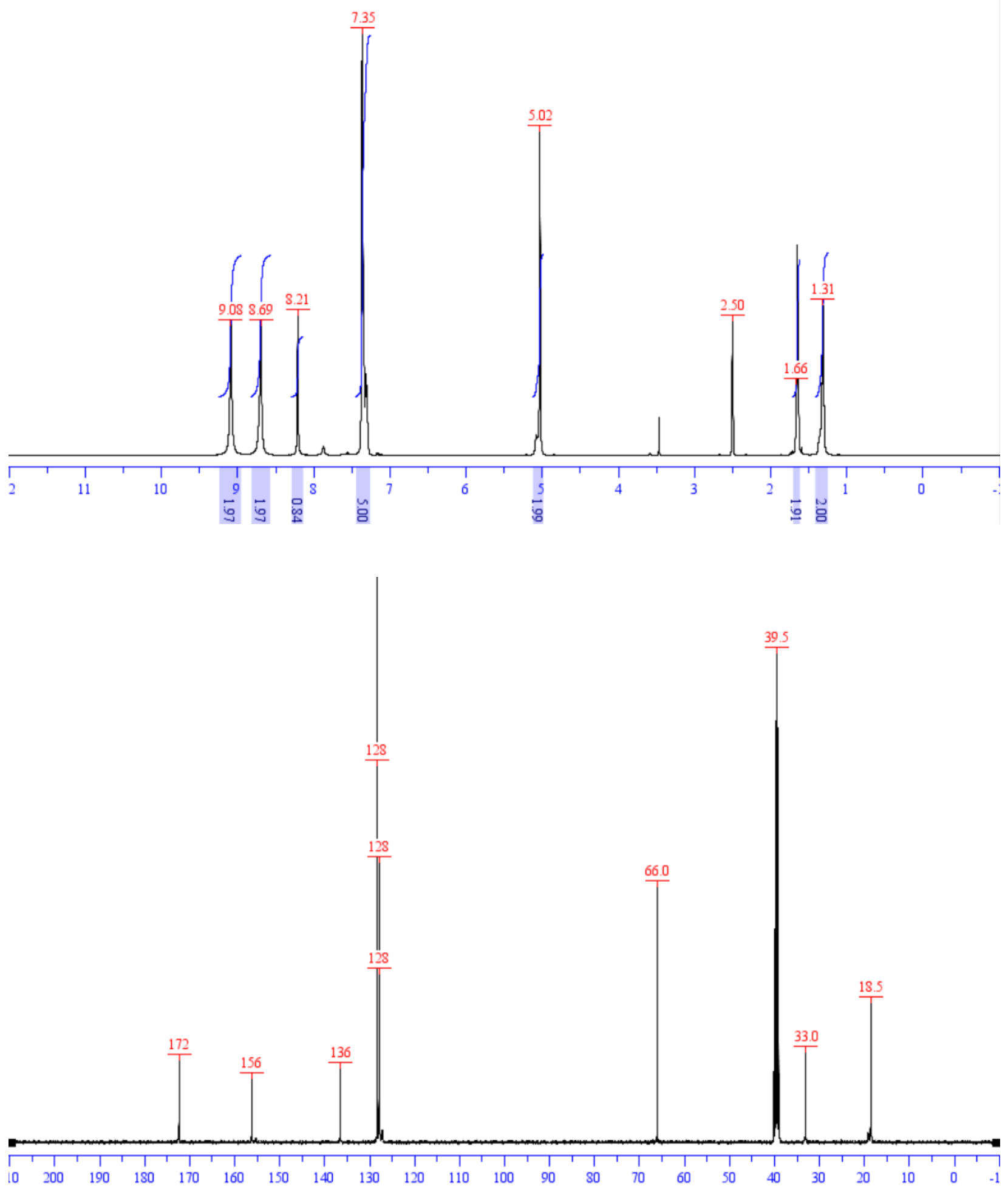
HPLC trace of $14-\mathrm{HCl}$ from $0.76 \mathrm{~kg}$ run

\begin{tabular}{|lll|}
\hline Inject Vol.: & 0.15 ul & \\
Eluent $A:$ & Water $0.04 \%$ TFA & \\
Eluent B: & Acetonitrile & \\
Column: & Zorbax RRHD SB-Aq, 2.1x50mm, 1.8um/USEAF01646 & @ 40.0 ${ }^{\circ} \mathrm{C}$ \\
Time Base: & iClass-MS02 & \\
Program Name: & G_005\%B_TFA_0,800mI_2,00min_200-800amu_ESIplus & $\begin{array}{l}\text { lonisation: ESI+ } \\
\text { Wavelength: } 210 \mathrm{~nm}\end{array}$ \\
\hline
\end{tabular}

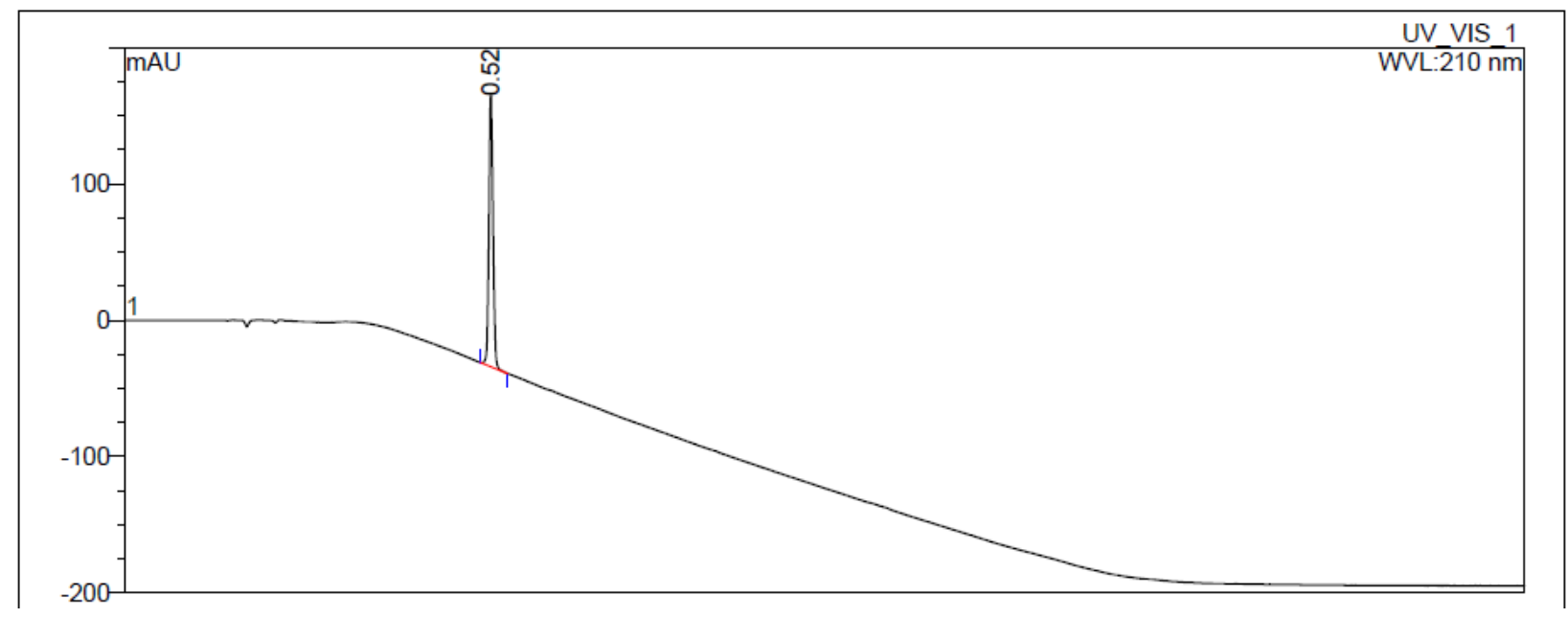

DSC of $14-\mathrm{HCl}$

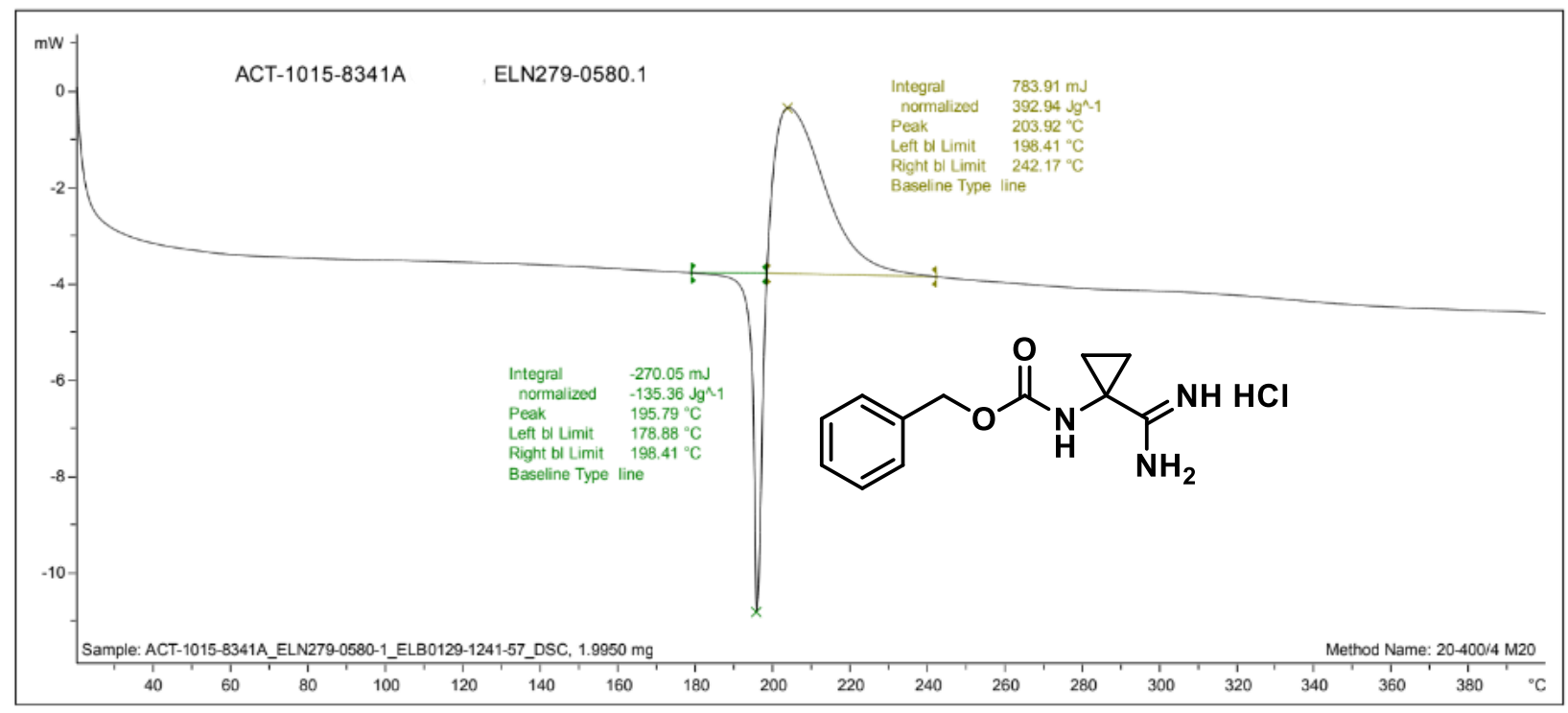


benzyl (1-(5-chloropyrimidin-2-yl)cyclopropyl)carbamate (21)
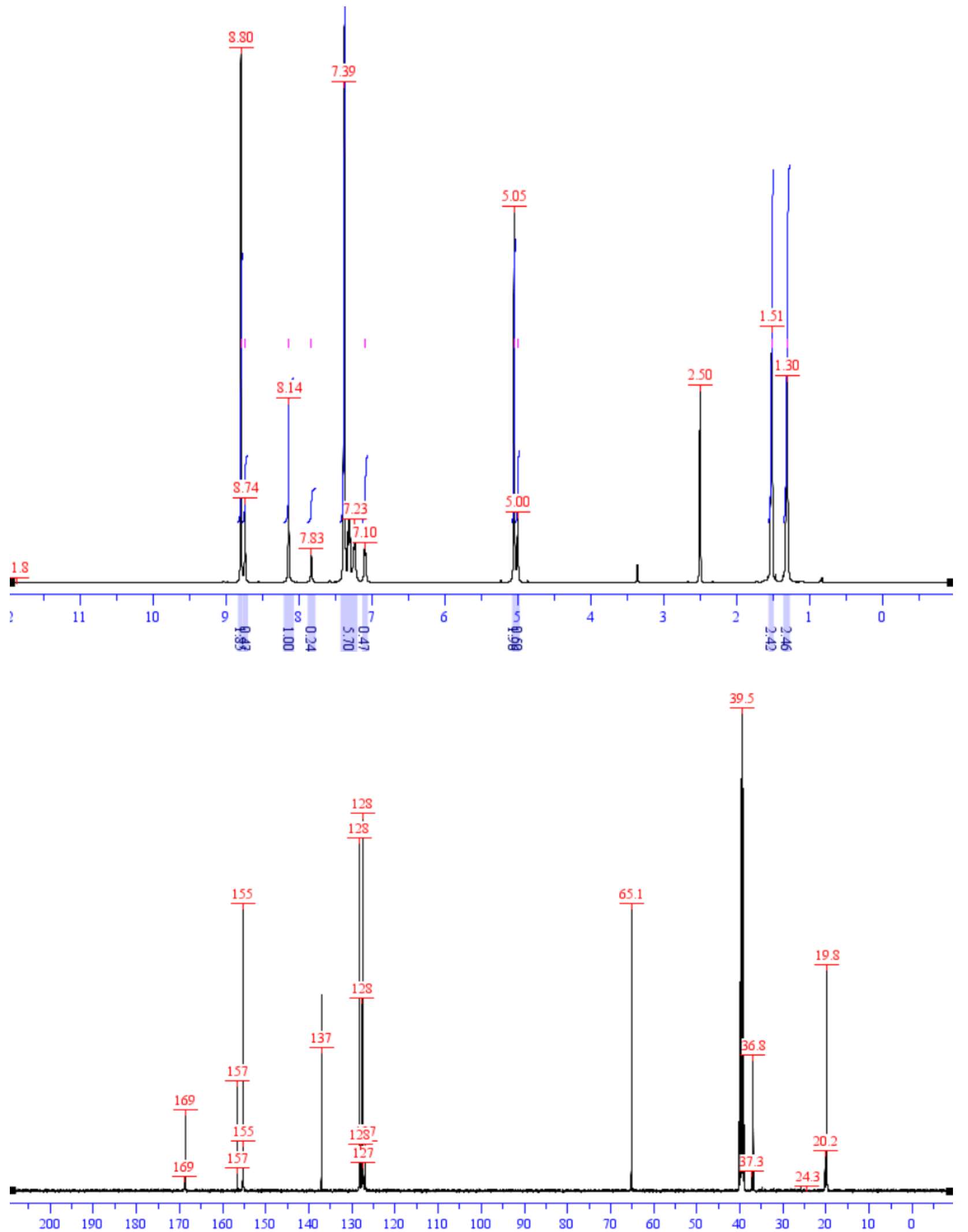
HPLC trace of $\mathbf{2 1}$ from $0.5 \mathrm{~kg}$ run

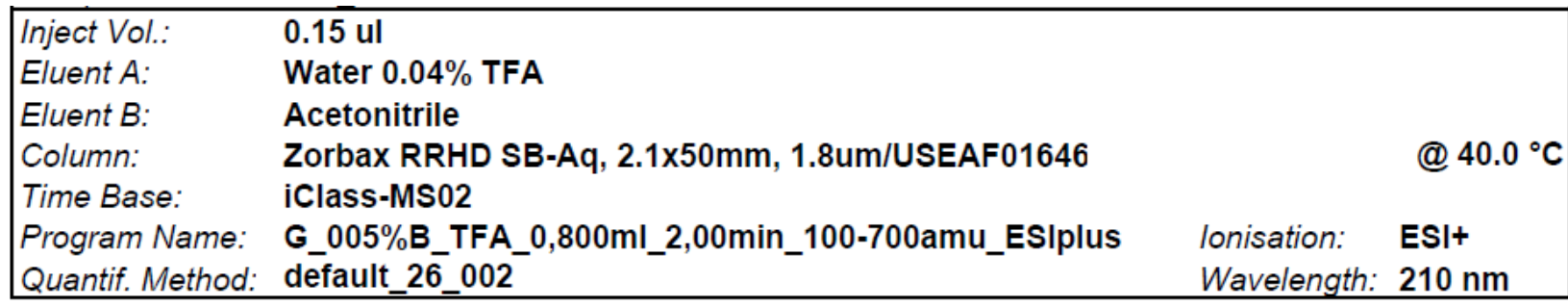

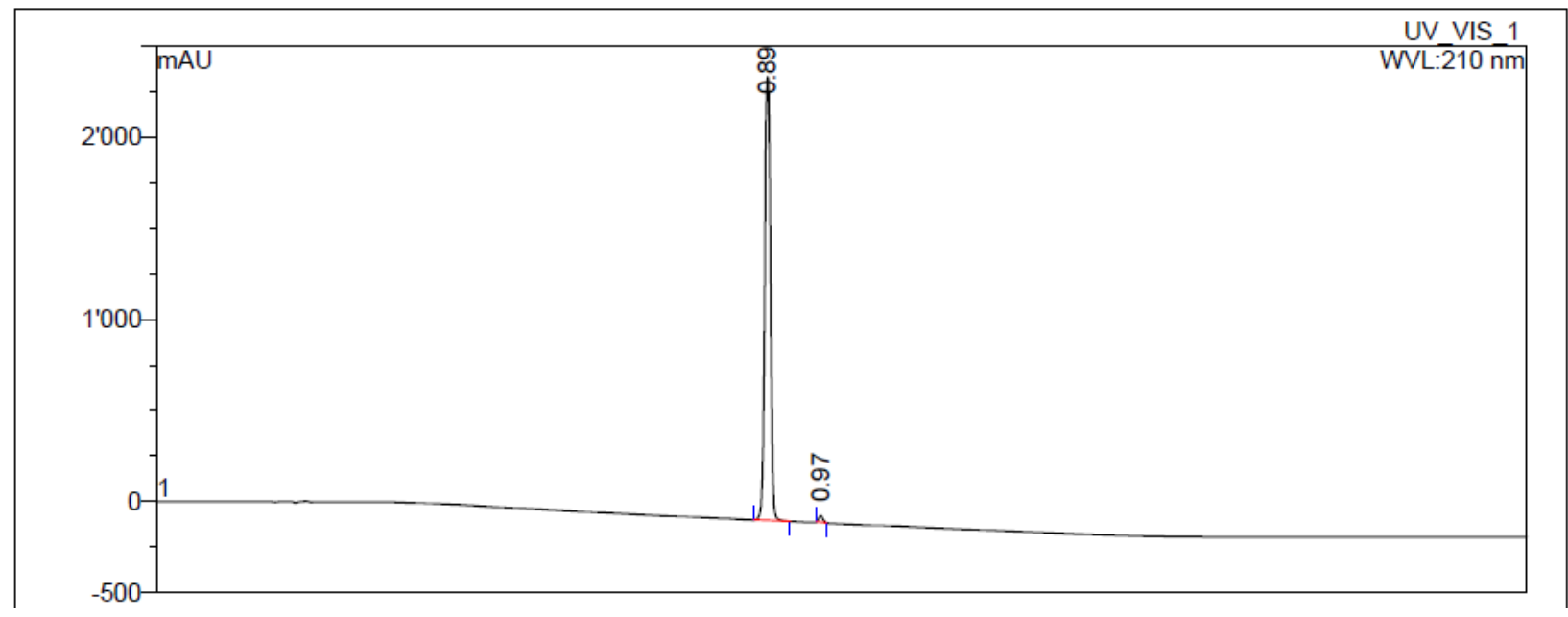

DSC of $\mathbf{2 1}$

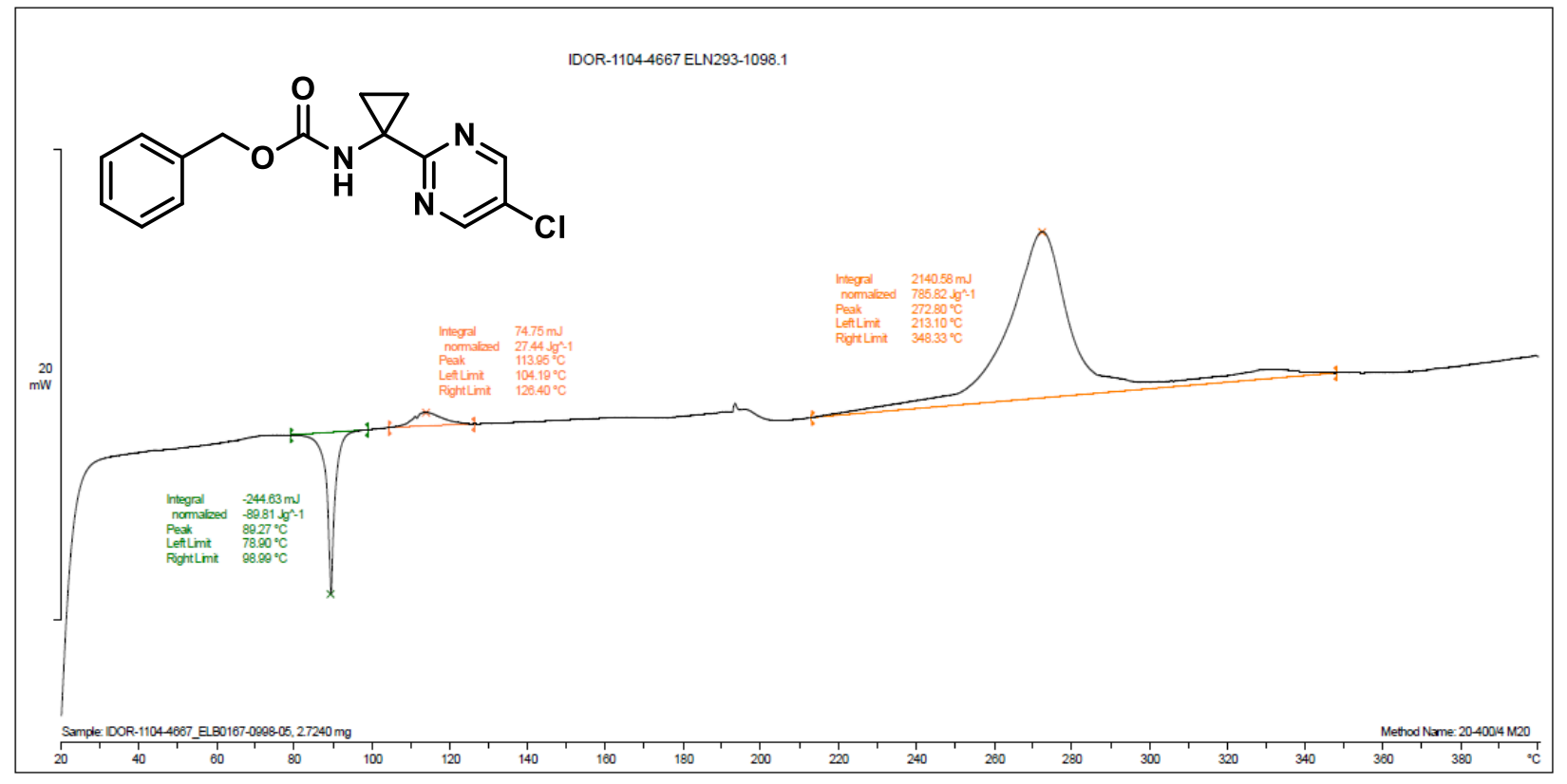


1-(pyrimidin-2-yl)cyclopropan-1-amine hydrochloride (1-HCI)
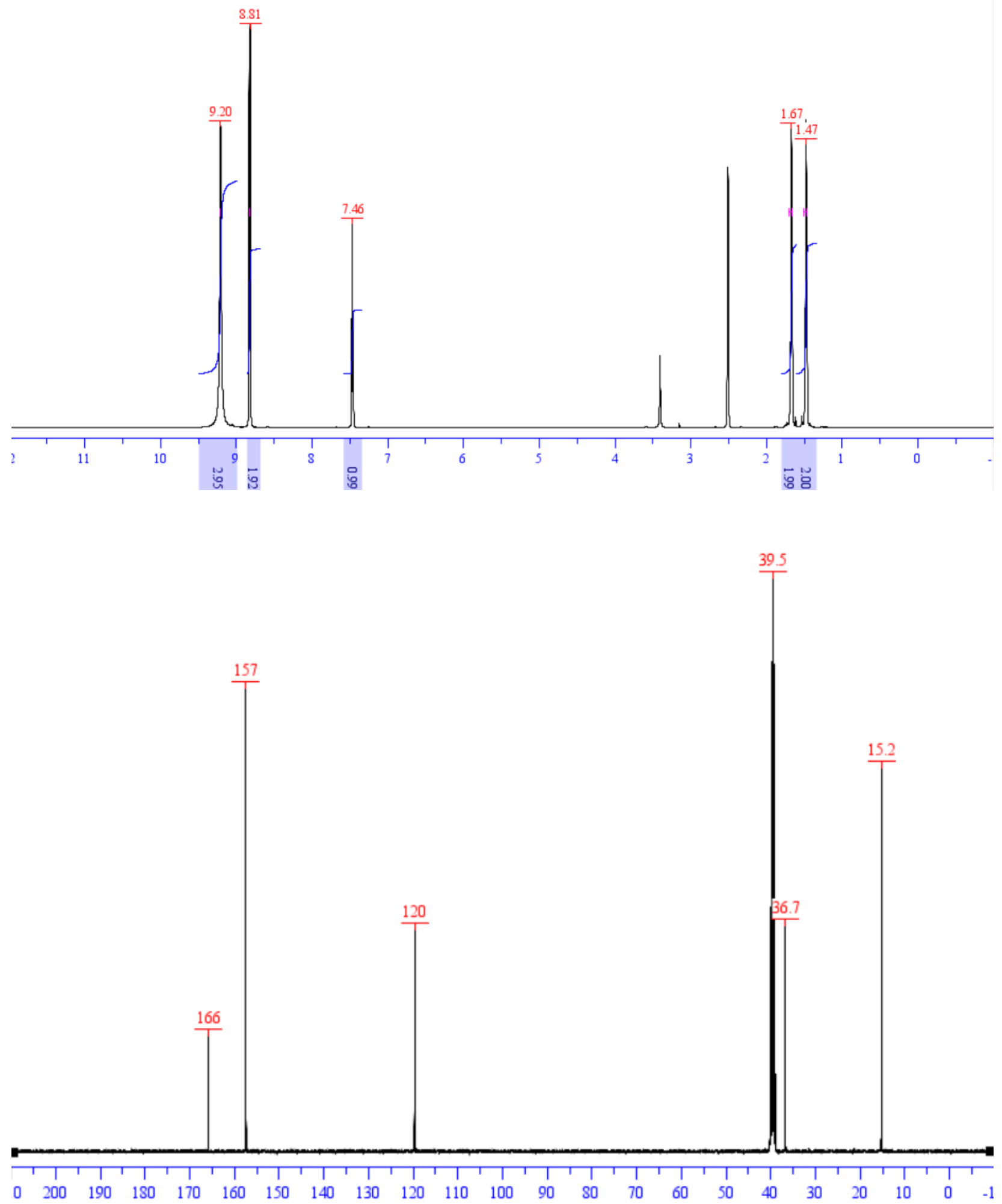
HPLC trace of $1-\mathbf{H C l}$ from $150 \mathrm{~g}$ run

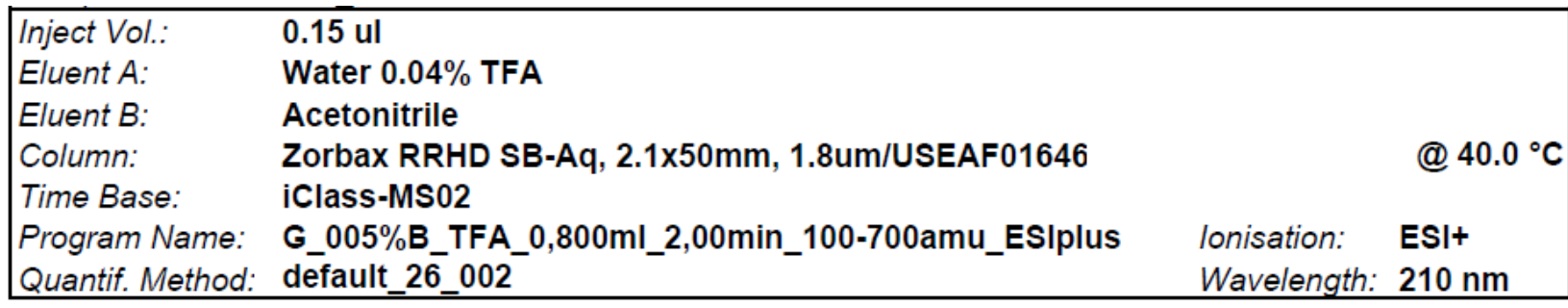

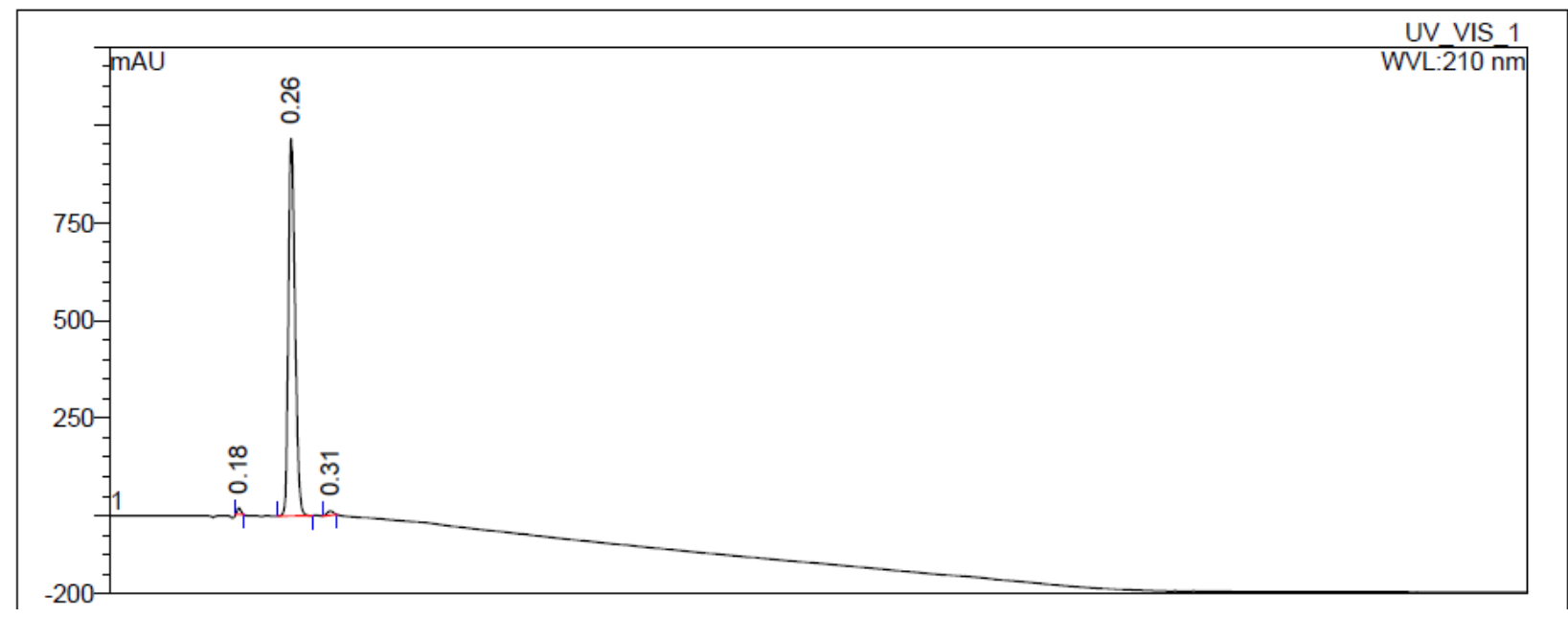

XRPD 1-HCl: Pattern A

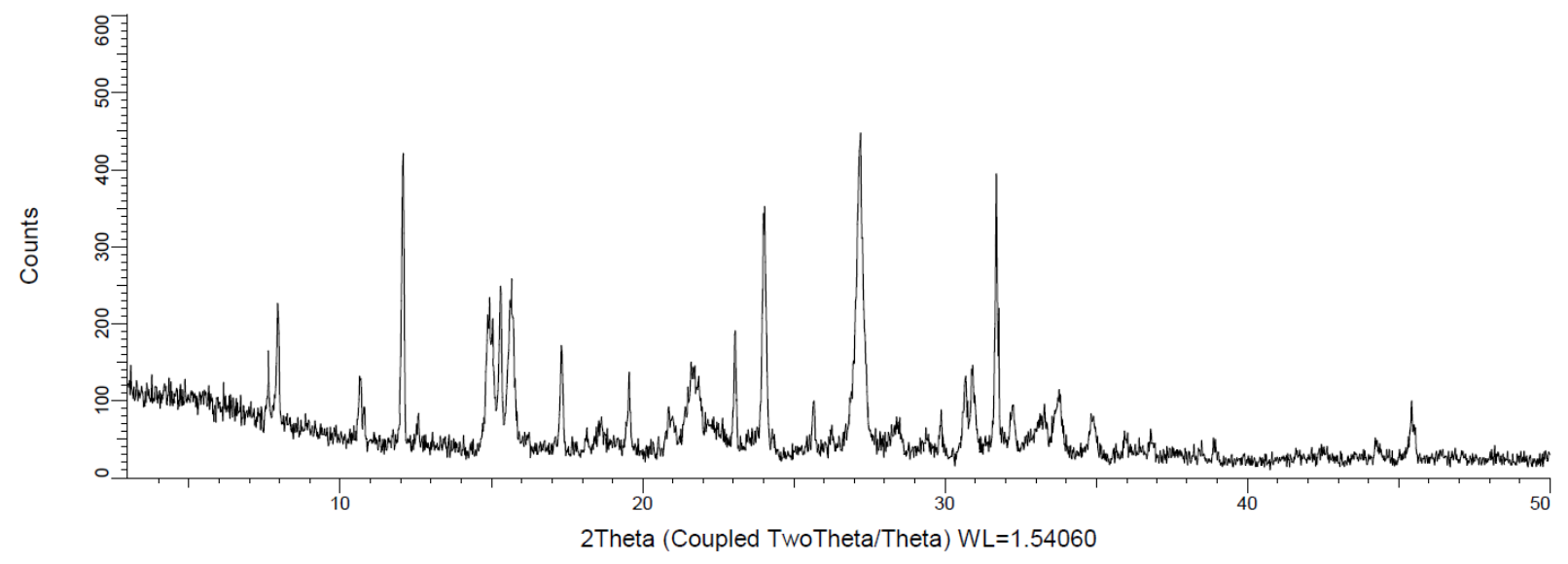




\section{DSC of $1-\mathrm{HCl}$}

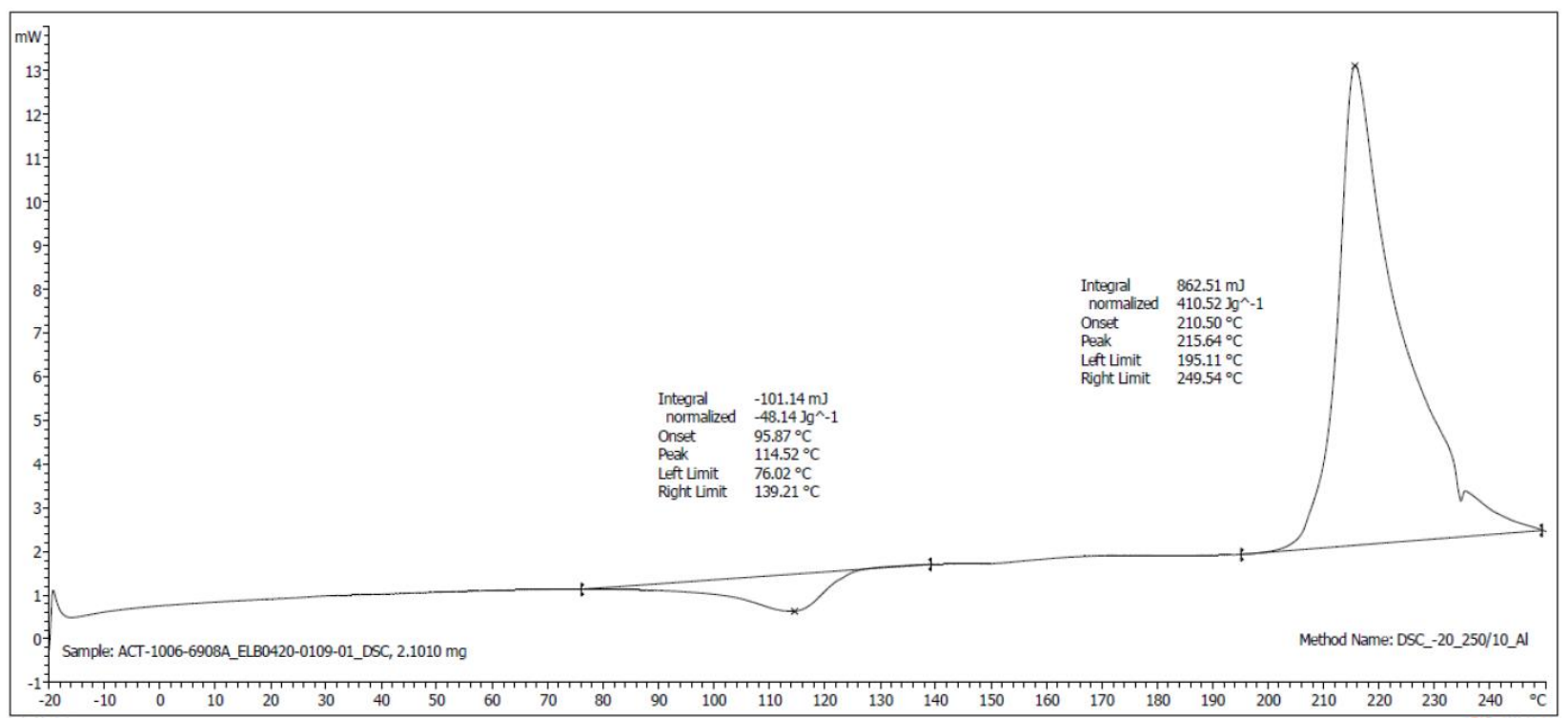

